\title{
Mercury Assessment and Monitoring Protocol for the Bear Creek Watershed, Colusa County, California
}

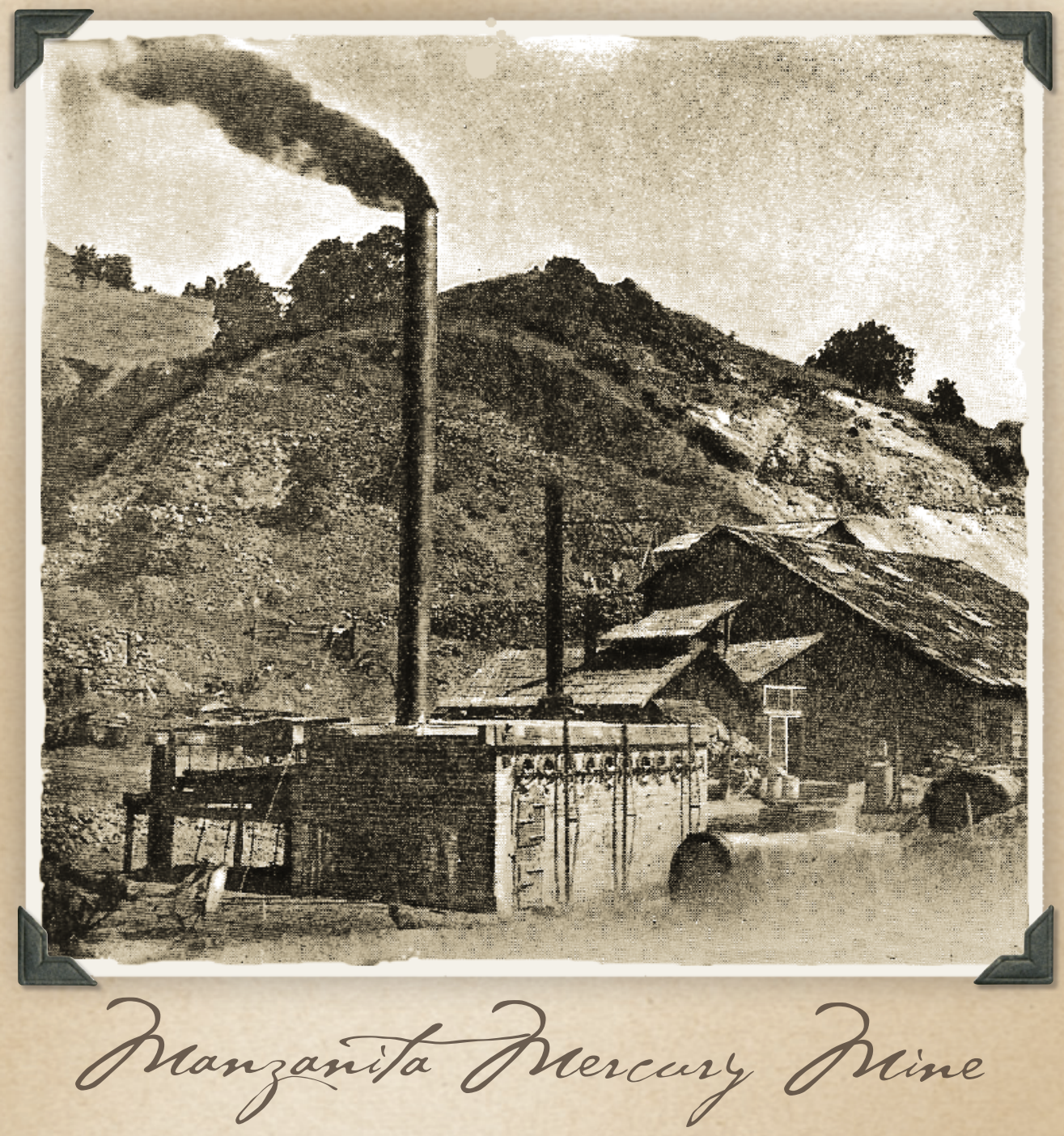

Scientific Investigations Report 2010-5018 
Cover: Historical photograph of the 10-pipe retort furnace, Manzanita Mine, Colusa County, which was used to process previously concentrated mercury ore, circa 1900. This photograph is from the 1903 California State Mining Bureau Bulletin 27. Credit to Ron Churchill, California Geological Survey. 


\section{Mercury Assessment and Monitoring Protocol for the Bear Creek Watershed, Colusa County, California}

By Thomas H. Suchanek, Roger L. Hothem, James J. Rytuba, and Julie L. Yee

Prepared for the Bureau of Land Management

Scientific Investigations Report 2010-5018 


\title{
U.S. Department of the Interior \\ KEN SALAZAR, Secretary
}

\section{U.S. Geological Survey \\ Marcia K. McNutt, Director}

\section{U.S. Geological Survey, Reston, Virginia: 2010}

\author{
For more information on the USGS — the Federal source for science about the Earth, its natural and living resources, \\ natural hazards, and the environment, visit http://www.usgs.gov or call 1-888-ASK-USGS \\ For an overview of USGS information products, including maps, imagery, and publications, \\ visit http://www.usgs.gov/pubprod \\ To order this and other USGS information products, visit http://store.usgs.gov
}

Any use of trade, product, or firm names is for descriptive purposes only and does not imply endorsement by the U.S. Government.

Although this report is in the public domain, permission must be secured from the individual copyright owners to reproduce any copyrighted materials contained within this report.

Suggested citation:

Suchanek, T.H., Hothem, R.L., Rytuba, J.J., and Yee, J.L., 2010, Mercury assessment and monitoring protocol for the Bear Creek Watershed, Colusa County, California: U.S. Geological Survey Scientific Investigations Report 2010-5018, $34 \mathrm{p}$. 


\section{Contents}

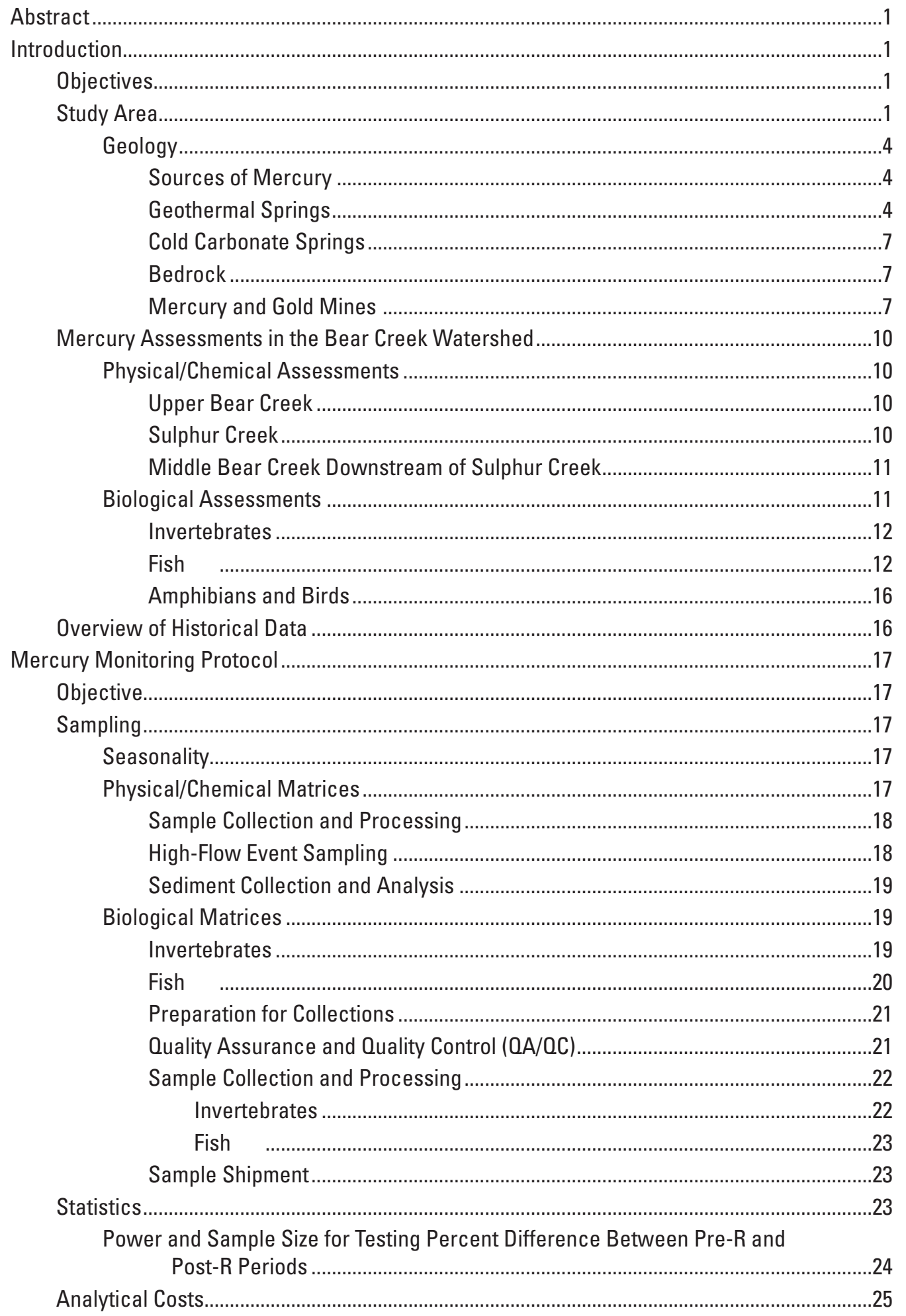




\section{Contents-Continued}

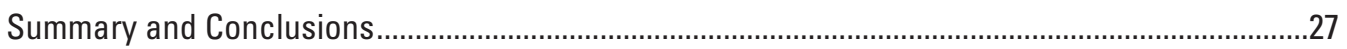

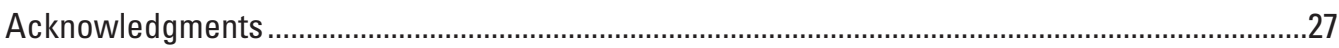

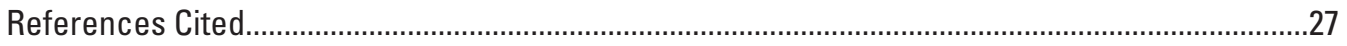

Appendix A. Fish Processing Form for Bear Creek Mercury Study .................................................31

Appendix B. Invertebrate Laboratory Processing Form for Bear Creek Mercury Study ................32

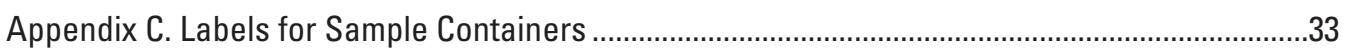

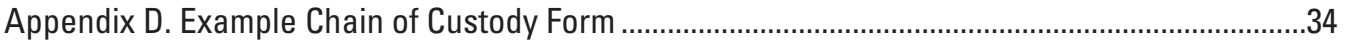

\section{Figures}

Figure 1. Map showing Bear Creek Watershed with locations of mines, springs, and proposed sampling locations for mercury monitoring

Figure 2. Geological map and ore deposits and geothermal springs located in the Clear Lake volcanic field, including the Bear Creek watershed

Figure 3. Map showing geology and $\mathrm{Hg}$ and Au deposits located in the Sulphur Creek tributary to Bear Creek

Figure 4. Map showing location of the Rathburn and Petray $\mathrm{Hg}$ mines and tributaries 1-4 that drain the mine area and release $\mathrm{Hg}$-enriched sediment into Bear Creek... 8

Figure 5. Map showing Cache Creek Watershed, including its two major tributaries, Bear Creek and North Fork Cache Creek; red dots indicate invertebrate mercury bioindicator sampling sites used by Slotton and others during 1995-97 ... 13

Figure 6. Map showing mercury concentrations ( $\mathrm{ppm} \mathrm{dw)} \mathrm{in} \mathrm{stream} \mathrm{invertebrates} \mathrm{from}$ the Cache Creek watershed in 1995

Figure 7. Map showing mercury (ppm dw) in stream invertebrates in the Bear Creek Watershed from D. Slotton collections in 1996

\section{Tables}

Table 1. Bear Creek watershed monitoring sites

Table 2. Available and Target* invertebrate families, Bear Creek ...................... 20

Table 3. Available and Target* ${ }^{*}$ fish species, Bear Creek ............................ 21

Table 4. Summary of invertebrate and fish sample collections for

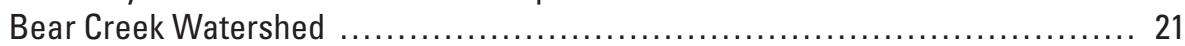

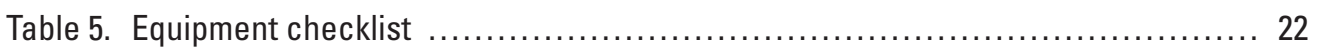

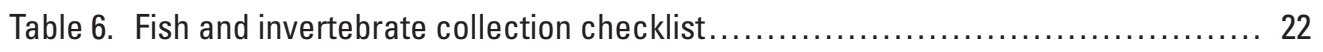

Table 7. Estimated costs of individual analyses .................................. 25

Table 8. Summary of water and sediment chemical analyses per site for Bear Creek watershed

Table 9. Summary of invertebrate and fish chemical analyses per site for Bear Creek watershed

Table 10. Estimated budget (in dollars) for Federal staff to conduct Bear Creek sampling based on 2009 costs 


\section{Conversion Factors, Datum, and Acronyms}

Conversion Factors

\begin{tabular}{|c|c|c|}
\hline Multiply & By & To obtain \\
\hline \multicolumn{3}{|c|}{ Length } \\
\hline inch (in.) & 2.54 & centimeter $(\mathrm{cm})$ \\
\hline inch (in.) & 25.4 & millimeter (mm) \\
\hline foot (ft) & 0.3048 & meter (m) \\
\hline mile (mi) & 1.609 & kilometer (km) \\
\hline \multicolumn{3}{|c|}{ Area } \\
\hline acre & 4,047 & square meter $\left(\mathrm{m}^{2}\right)$ \\
\hline acre & 0.4047 & hectare (ha) \\
\hline acre & 0.004047 & square kilometer $\left(\mathrm{km}^{2}\right)$ \\
\hline \multicolumn{3}{|c|}{ Volume } \\
\hline gallon (gal) & 3.785 & liter (L) \\
\hline gallon (gal) & 0.003785 & cubic meter $\left(\mathrm{m}^{3}\right)$ \\
\hline cubic inch $\left(\mathrm{in}^{3}\right)$ & 16.39 & cubic centimeter $\left(\mathrm{cm}^{3}\right)$ \\
\hline cubic inch $\left(\mathrm{in}^{3}\right)$ & 0.01639 & liter (L) \\
\hline cubic foot $\left(\mathrm{ft}^{3}\right)$ & 0.02832 & cubic meter $\left(\mathrm{m}^{3}\right)$ \\
\hline \multicolumn{3}{|c|}{ Flow rate } \\
\hline cubic foot per second $\left(\mathrm{ft}^{3} / \mathrm{s}\right)$ & 0.02832 & cubic meter per second $\left(\mathrm{m}^{3} / \mathrm{s}\right)$ \\
\hline gallon per minute (gal/min) & 0.06309 & liter per second (L/s) \\
\hline \multicolumn{3}{|c|}{ Mass } \\
\hline gram (g) & 0.03527 & ounce, avoirdupois (oz) \\
\hline kilogram (kg) & 2.205 & pound, avoirdupois (lb) \\
\hline microgram $(\mu \mathrm{g})$ & 0.0000000353 & ounce, avoirdupois (oz) \\
\hline milligram (mg) & 0.0000353 & ounce, avoirdupois (oz) \\
\hline nanogram (ng) & 0.0000000000353 & ounce, avoirdupois (oz) \\
\hline ounce, avoirdupois (oz) & 28.35 & gram (g) \\
\hline pound, avoirdupois (lb) & 0.4536 & kilogram (kg) \\
\hline ton, short $(2,000 \mathrm{lb})$ & 0.9072 & megagram (Mg) \\
\hline ton, long $(2,240 \mathrm{lb})$ & 1.016 & megagram (Mg) \\
\hline
\end{tabular}

Temperature in degrees Celsius $\left({ }^{\circ} \mathrm{C}\right)$ may be converted to degrees Fahrenheit $\left({ }^{\circ} \mathrm{F}\right)$ as follows:

$$
{ }^{\circ} \mathrm{F}=\left(1.8 \times^{\circ} \mathrm{C}\right)+32 .
$$

Temperature in degrees Fahrenheit $\left({ }^{\circ} \mathrm{F}\right)$ may be converted to degrees Celsius $\left({ }^{\circ} \mathrm{C}\right)$ as follows:

$$
{ }^{\circ} \mathrm{C}=\left({ }^{\circ} \mathrm{F}-32\right) / 1.8 \text {. }
$$

Specific conductance is given in microsiemens per centimeter at 25 degrees Celsius $(\mu \mathrm{S} / \mathrm{cm}$ at $\left.25^{\circ} \mathrm{C}\right)$.

Concentrations of chemical constituents in water are given in milligrams per liter $(\mathrm{mg} / \mathrm{L}$, parts per million), micrograms per liter ( $\mu \mathrm{g} / \mathrm{L}$, parts per billion), or nanograms per liter ( $\mathrm{ng} / \mathrm{L}$, parts per trillion).

Concentrations of chemical constituents in tissues are given in micrograms per gram $(\mu \mathrm{g} / \mathrm{g}$, parts per million).

Concentrations of chemical constituents in sediments are given in micrograms per gram $(\mu \mathrm{g} / \mathrm{g}$, parts per million) or nanograms per gram (ng/g, parts per billion). 


\section{Conversion Factors, Datum, and Acronyms-Continued}

\begin{tabular}{ll} 
Datum & \\
Horizontal coordinate information is referenced to the North American Dat \\
& \\
Acronyms & \\
\hline ANOVA & Analysis of variance \\
ASTM & American Society for Testing and Materials \\
Au & Gold \\
B & Boron \\
BLM & Bureau of Land Management \\
CDFG & California Department of Fish and Game \\
Cl- & Chloride \\
CVRWQCB & Central Valley Regional Water Quality Control Board \\
DOC & Dissolved organic carbon \\
Fe & Iron \\
FLPE & Fluorinated polyethylene \\
HCl & Hydrochloric acid \\
Hg & Mercury \\
K & Potassium \\
Li & Lithium \\
MMeHg & Monomethyl mercury \\
Na & Sodium \\
NAWQA & National Water-Quality Assessment \\
ORP & Oxidative-reductive potential \\
Rb & Rubidium \\
S & Sulfur \\
Se & Selenium \\
Sr & Strontium \\
TMDL & Total maximum daily load \\
TotHg & Total mercury \\
USBM & U.S. Bureau of Mines \\
USEPA & U.S. Environmental Protection Agency \\
USGS & U.S. Geological Survey \\
W & Tungsten \\
YSI & Yellow Springs Instruments \\
\hline &
\end{tabular}




\title{
Mercury Assessment and Monitoring Protocol for the Bear Creek Watershed, Colusa County, California
}

\author{
By Thomas H. Suchanek, Roger L. Hothem, James J. Rytuba, and Julie L. Yee
}

\section{Abstract}

This report summarizes the known information on the occurrence and distribution of mercury (Hg) in physical/ chemical and biological matrices within the Bear Creek watershed. Based on these data, a matrix-specific monitoring protocol for the evaluation of the effectiveness of activities designed to remediate Hg contamination in the Bear Creek watershed is presented. The monitoring protocol documents procedures for collecting and processing water, sediment, and biota for estimation of total Hg (TotHg) and monomethyl mercury (MMeHg) in the Bear Creek watershed. The concurrent sampling of TotHg and MMeHg in biota as well as water and sediment from 10 monitoring sites is designed to assess the relative bioavailability of $\mathrm{Hg}$ released from Hg sources in the watershed and identify environments conducive to Hg methylation. These protocols are designed to assist landowners, land managers, water quality regulators, and scientists in determining whether specific restoration/ mitigation actions lead to significant progress toward achieving water quality goals to reduce $\mathrm{Hg}$ in Bear and Sulphur Creeks.

\section{Introduction}

\section{Objectives}

The objectives of this report are (1) to summarize the known information on the occurrence and distribution of mercury (hereafter Hg) in physical/chemical and biological matrices within the Bear Creek watershed, and (2) using this information as a basis, develop a matrix-specific monitoring protocol for the evaluation of the effectiveness of activities designed to remediate Hg contamination in the Bear Creek watershed.

\section{Study Area}

Bear Creek, Cache Creek, and the North Fork of Cache Creek are the major tributaries of the Cache Creek watershed, encompassing 2,978 km² (ig. 1). The Cache Creek watershed contains soils naturally enriched in mercury (Hg) as well as natural springs (both hot and cold) with varying levels of aqueous $\mathrm{Hg}$. All three tributaries are known to be significant sources of anthropogenically derived $\mathrm{Hg}$ from historic mines, both Hg and gold (Au), and associated ore storage/processing sites and facilities (D.G. Slotton, unpub. data, 1995; Foe and Croyle, 1998; Schwarzbach and others, 2001; Tetra Tech EMI, 2003; Domagalski and others, 2004; Slotton, 2004; Suchanek and others, 2004, 2008a, 2009; Gassel and others, 2005).

The Bear Creek watershed is located in the northeastern part of the Clear Lake volcanic field that is composed of Pliocene to Holocene volcanic centers (fig. 2). It is the youngest of the volcanic fields that formed along the margin of the North American plate as the Mendocino triple junction migrated northward along the coast of California. The high heat flow associated with the volcanism resulted in the formation of $\mathrm{Hg}$ and gold-silver (Au-Ag) ore deposits. In addition, numerous active hot springs and gas vents are present throughout the volcanic field, including the Bear Creek watershed (figs. 1, 2, $\underline{3}$, $\underline{4}$ ). The ore deposits are the northernmost and youngest in the Coast Range Hg mineral belt. Mercury and Au-Ag deposits are present on the west side of the Bear Creek watershed and in the drainage area of Sulphur Creek, a major tributary of Bear Creek. Hot springs that are actively depositing $\mathrm{Hg}$ and $\mathrm{Au}$ are associated with some of these $\mathrm{Hg}-\mathrm{Au}$ deposits. The geothermal springs reflect the waning stage of the hydrothermal systems that formed the $\mathrm{Hg}$ and $\mathrm{Au}$ deposits. Cold to weakly thermal carbonate springs also are present in the Bear Creek watershed. These springs are actively depositing travertine, and some of these fluids contain anomalously high concentrations of $\mathrm{Hg}$. The hot springs and cold carbonate springs are characterized by high salinity waters that are derived from evolved connate water (water trapped in pores during deposition of a sediment) present in the sedimentary rocks of the Great Valley sequence.

The Bear Creek watershed is unusual in that meteoric water (groundwater derived from precipitation) does not always dominate the composition of waters in Bear Creek and some of its tributaries. High salinity effluent from the numerous geothermal springs, cold carbonate springs, and high salinity groundwater is a significant source of water to Bear Creek and contributes to its relatively high conductivity. 


\section{Bear Creek Watershed Overview}

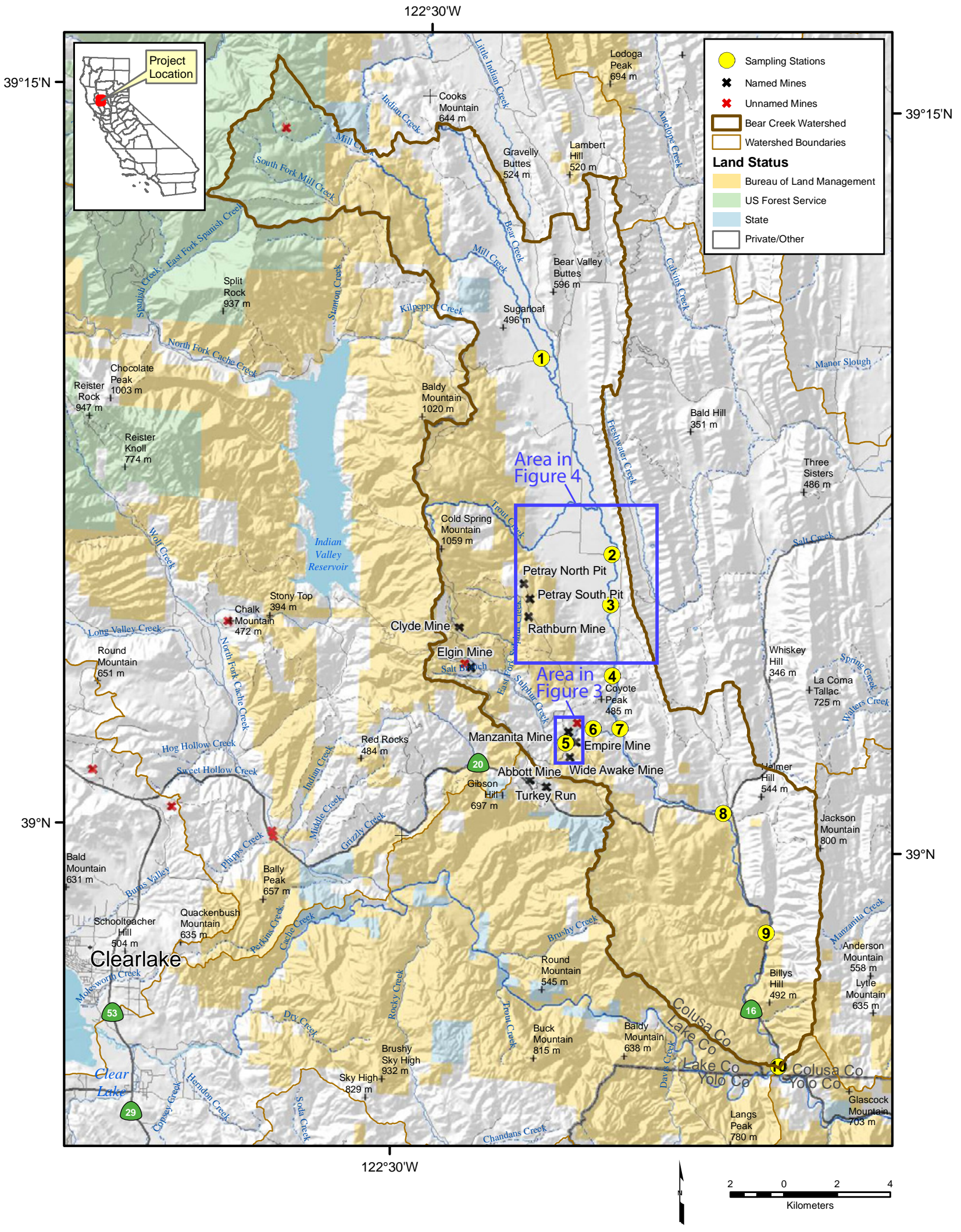

Figure 1. Bear Creek Watershed with locations of mines, springs, and proposed sampling locations for mercury monitoring. Locations of figures 3 and 4 are indicated on this figure. 


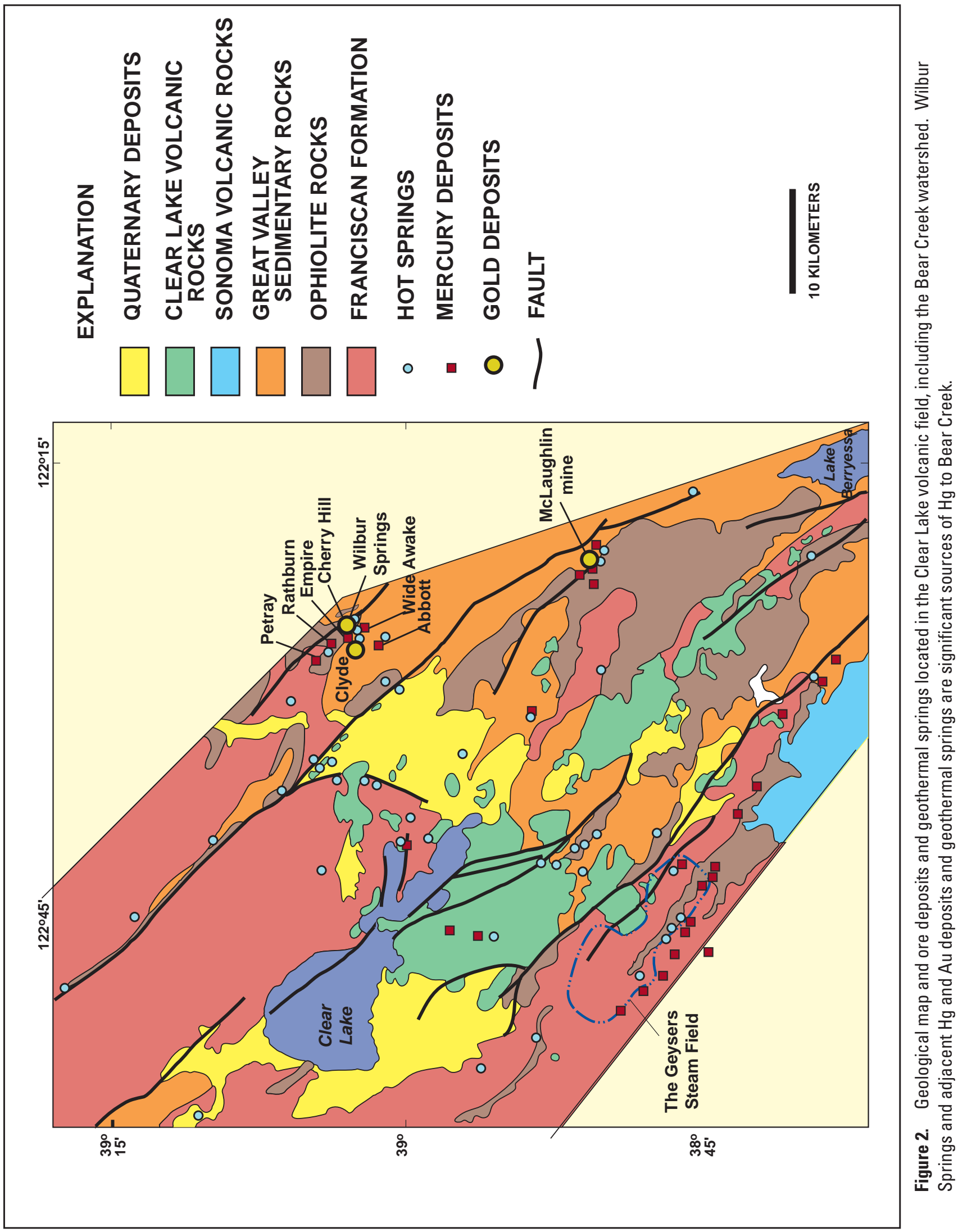


Mercury Assessment and Monitoring Protocol for the Bear Creek Watershed, Colusa County, California

Conductivity under low-flow conditions is $800 \mu \mathrm{S} / \mathrm{cm}$ in the upper part of the watershed and increases to $1,200 \mu \mathrm{S} / \mathrm{cm}$ just upstream of the confluence with Sulphur Creek. During the dry season, the effluent from saline springs and groundwater predominate, and Bear Creek water reaches its maximum salinity. During the wet season, runoff reduces the salinity of Bear Creek, and the waters of Bear Creek and its tributaries are predominantly meteoric. The effluent from the high salinity springs also contains elevated concentrations of Hg, sulfate, boron (B), and tungsten (W) that significantly affect water quality, especially under low-flow conditions during the dry season, and during low rainfall years. Important components that contribute to the methylation of $\mathrm{Hg}$ include sulfate, salinity, dissolved organic carbon (DOC), and Hg. Thus, seasonal changes in the water chemistry of Bear Creek and some of its tributaries, especially Sulphur Creek, can affect the physical and chemical variables that control Hg methylation. It is, therefore, important that the monitoring protocol specify sampling under similar seasonal and flow conditions so that results may be compared under similar flow conditions.

\section{Geology}

The north-south trend of Bear Creek reflects a major geologic boundary in California that is termed the Coast Range fault. The fault separates Cretaceous sedimentary rocks of the Great Valley sequence and the Coast Range ophiolite to the east from rocks of the Franciscan Complex to the west (fig. 2). Initial movement along the Coast Range fault thrust Great Valley sequence rocks above the similar age Franciscan Complex. This initial period of compressional faulting was followed by downward displacement along lowangle detachment faults. The hills that comprise the east side of Bear Valley consist of Great Valley sequence sandstones, siltstones, and shales that have been tilted upward and dip to the east at angles up to 45 degrees. These sedimentary rocks comprise the floor of Bear Valley as well as the first low hills on the west side of the valley. The uplifted west side of Bear Valley is bounded by a series of faults that separates Great Valley sequence rocks to the east from rocks of the Franciscan Complex and Coast Range ophiolite to the west where these rocks form the high hills of Walker Ridge. The Rathburn and Petray Hg deposits are hosted in hydrothermally altered Coast Range ophiolite, however, the Hg deposits in the Sulphur Creek watershed are hosted in sedimentary rocks of the Great Valley sequence.

\section{Sources of Mercury}

Both natural and anthropogenic sources contribute Hg to Bear Creek and its tributaries. The natural sources consist of geothermal springs, cold carbonate springs, and hydrothermally altered rock associated with $\mathrm{Hg}$ and $\mathrm{Au}$ deposits, and unaltered rock. The anthropogenic sources include abandoned $\mathrm{Hg}$ mines, Au mines, and ore-processing facilities present in the Bear Creek and Sulphur Creek watersheds. The geothermal springs are located within the Sulphur Creek watershed and include Wilbur Springs, and, farther upstream, Jones Fountain of Life, Elbow, Blank, and several hot springs within the Elgin Hg deposit. The Jones Fountain of Life and two smaller hot springs (Blank and Elbow) occur on the eastern margin of the Cherry Hill Au deposit and adjacent to the Manzanita Hg deposit. Cold carbonate springs are present throughout the Bear Creek watershed and are localized along faults that bound the east and west side of Bear Valley and the east side of the lower reach of Bear Creek. A large number of cold saline springs are localized along the Bear Fault (located on the west side of Bear Valley and to the east of the Rathburn and Petray $\mathrm{Hg}$ mines). Effluent from these springs, along with saline groundwater, significantly increases the conductivity of Bear Creek water (Slowey and Rytuba, 2007). Downstream of the input from the cold springs, the chloride $\left(\mathrm{Cl}^{-}\right)$concentration of Bear Creek is 94 milligrams per liter $(\mathrm{mg} / \mathrm{L}$, ppm = parts per million) (Site 3, table 1) as compared to $30 \mathrm{ppm}$ upstream of the input of the springs (Site 2, table 1), an increase of 300 percent. Because of the addition of saline groundwater, the $\mathrm{Cl}^{-}$concentration of Bear Creek increases to $150 \mathrm{ppm}$ just upstream of the confluence with Sulphur Creek (Site 4, table 1). However, sulfate concentration in the $6.5-\mathrm{km}$ reach of Bear Creek from Site 2 to Site 4 remains about the same, at a relatively high concentration of 17-19 ppm. The conductivity of Bear Creek increases substantially downstream of its confluence with Sulphur Creek because of the effluent from high salinity hot springs in the Sulphur Creek watershed. During the dry season, Sulphur Creek waters are composed primarily of saline, hot spring effluent that also contains elevated concentrations of sulfate, Hg, W, B, and iron (Fe).

\section{Geothermal Springs}

In the lower part of the Sulphur Creek watershed, geothermal springs are localized along the Resort fault zone. At Wilbur Springs, several hot spring vents form a coalescing travertine terrace along the northern bank of Sulphur Creek (figs. 2 and $\underline{3}$ ). The temperature of the Wilbur Hot Springs geothermal waters ranges as high as $56^{\circ} \mathrm{C}$, and the waters have very high concentrations of $\mathrm{Cl}^{-}(10,900 \mathrm{ppm})$ and B (280 ppm). The concentration of total $\mathrm{Hg}$ (TotHg) in the Wilbur springs ranges from 6.4 to $6.7 \mu \mathrm{g} / \mathrm{L}$ ( $\mathrm{ppb}=$ parts per billion) (Janik and others, 1994). Suchanek and others (2004) measured the geothermal waters where they feed the hot baths at the Wilbur Springs Resort and reported TotHg concentrations ranging from 3.5 to $7.3 \mathrm{ppb}$ with 26 to 69 percent of the TotHg present in the dissolved fraction. Black sediment that precipitates from the hot spring water contains $27 \mathrm{ppm}$ TotHg and $4.3 \mathrm{ppm}$ Au (Peters, 1991). This Hg-enriched sediment enters Sulphur Creek from the hot spring vent area as the hot spring effluent cools and flows over the travertine terrace. 
Table 1. Bear Creek watershed monitoring sites (NAD 83).

\begin{tabular}{|c|c|c|c|c|}
\hline Site No. & Monitoring site & Latitude & Longitude & $\begin{array}{l}\text { Distance from } \\
\text { Cache Creek } \\
(\mathrm{km})\end{array}$ \\
\hline 1 & $\begin{array}{l}\text { Milk Creek at Brim Road; upper watershed } \\
\text { characterization above known mercury sources }\end{array}$ & $39^{\circ} 09^{\prime} 46.90^{\prime \prime} \mathrm{N}$ & $122^{\circ} 26^{\prime} 50.20^{\prime \prime} \mathrm{W}$ & 34.80 \\
\hline 2 & $\begin{array}{l}\text { Bear Creek at bridge above tributaries from } \\
\text { Rathburn Petray; above all known mine input } \\
\text { and to be used for comparison with site } 3\end{array}$ & $39^{\circ} 05^{\prime} 51.40^{\prime} \mathrm{N}$ & $122^{\circ} 24^{\prime} 48.90^{\prime \prime} \mathrm{W}$ & 25.78 \\
\hline 3 & $\begin{array}{l}\text { Bear Creek downstream of Site 2; assess input } \\
\text { from tributaries from Rathburn-Petray mines } \\
\text { and cold saline springs along Bear Fault }\end{array}$ & $39^{\circ} 4^{\prime}$ 50.27” N & $122^{\circ} 24^{\prime} 48.1^{\prime \prime} \mathrm{W}$ & 23.65 \\
\hline 4 & $\begin{array}{l}\text { Bear Creek upstream of Sulphur Creek } \\
\text { (Hamilton); assess attenuation of input from } \\
\text { Rathburn-Petray mines }\end{array}$ & $39^{\circ} 03^{\prime} 24.00^{\prime \prime} \mathrm{N}$ & $122^{\circ} 24^{\prime} 41.00^{\prime \prime} \mathrm{W}$ & 20.74 \\
\hline 5 & $\begin{array}{l}\text { Sulphur Creek above Wilbur Hot Springs and } \\
\text { most mines; assess input from upper watershed } \\
\text { and Elgin mine and geothermal springs }\end{array}$ & $39^{\circ} 02^{\prime} 0.40^{\prime \prime} \mathrm{N}$ & $122^{\circ} 25^{\prime} 49.80^{\prime \prime} \mathrm{W}$ & 21.41 \\
\hline 6 & $\begin{array}{l}\text { Sulphur Creek at USGS Gauge; assess input } \\
\text { from geothermal springs and mines }\end{array}$ & $39^{\circ} 02^{\prime} 19.0 ” \mathrm{~N}$ & $122^{\circ} 25^{\prime} 8.0^{\prime \prime} \mathrm{W}$ & 19.92 \\
\hline 7 & $\begin{array}{l}\text { Bear Creek downstream of Sulphur Creek; } \\
\text { assess impact of input from Sulphur Creek }\end{array}$ & $39^{\circ} 02^{\prime} 20.23^{\prime \prime} \mathrm{N}$ & $122^{\circ} 24^{\prime} 25.93^{\prime \prime} \mathrm{W}$ & 18.46 \\
\hline 8 & $\begin{array}{l}\text { Bear Creek at Highway } 20 \text { Bridge; assess } \mathrm{Hg} \\
\text { methylation and transport from watershed } \\
\text { impacted by mines and geothermal springs }\end{array}$ & $39^{\circ} 0 ’ 41.78^{\prime \prime} \mathrm{N}$ & $122^{\circ} 21^{\prime} 40.34^{\prime \prime} \mathrm{W}$ & 12.33 \\
\hline 9 & $\begin{array}{l}\text { Bear Creek at Thompson Canyon Bridge; } \\
\text { assess Hg methylation in area of low gradient } \\
\text { and cattle grazing }\end{array}$ & $38^{\circ} 58^{\prime} 18.60^{\prime \prime} \mathrm{N}$ & $122^{\circ} 20^{\prime} 26.60^{\prime \prime} \mathrm{W}$ & 6.73 \\
\hline 10 & $\begin{array}{l}\text { Bear Creek just upstream of the confluence } \\
\text { with Cache Creek; assess Hg and MMeHg } \\
\text { released from entire Bear Creek watershed }\end{array}$ & $38^{\circ} 55^{\prime} 37.00^{\prime \prime} \mathrm{N}$ & $122^{\circ} 20^{\prime} 0.00^{\prime \prime} \mathrm{W}$ & 0.08 \\
\hline
\end{tabular}

Elbow spring, located on the southern bank of Sulphur Creek (fig. 3), has the highest water $\mathrm{Cl}^{-}$concentration (13,390 ppm) and TotHg concentration (61.0 ppb) of the geothermal springs in the Sulphur Creek watershed. The black precipitate at the vent contains $179 \mathrm{ppm}$ TotHg and $12.1 \mathrm{ppm}$ Au (Janik and others, 1994). Several unnamed hot spring vents occur in Sulphur Creek downstream of the Elbow spring and precipitate similar black sediment. Under low-flow conditions, the fine-grained precipitate accumulates in this section of Sulphur Creek until the first high-flow event of the wet season transports the Hg-enriched sediment downstream into Bear Creek. Upstream of the Elbow spring is Jones Fountain of Life, a spring that erupts about every 30 minutes with a maximum flow of $1.5 \mathrm{~L} / \mathrm{sec}$. The water has a $\mathrm{Cl}^{-}$concentration of 11,260 ppm, a TotHg concentration of $22.0 \mathrm{ppb}$, and an estimated TotHg flux from this spring of $1.1 \mathrm{~kg} / \mathrm{yr}$ (Janik and others, 1994). Suchanek and others (2004) reported that the TotHg concentration in this spring ranges from 24.3 to 39.7 ppb, with 14 to 35 percent of the TotHg in the dissolved fraction. As the geothermal water cools and flows from the vent, it precipitates black, fine-grained sediment that contains
157 ppm TotHg and 4 ppm Au. The black precipitate consists of an amorphous aluminum silicate that contains Fe, sulfur (S), and potassium (K). Crystals of cinnabar (up to $1 \mathrm{~mm}$ in size) and barite (up to $6 \mathrm{~mm}$ ) occur within the amorphous black precipitate. Blank hot spring is located south of Sulphur Creek, and effluent and precipitate from the hot spring do not enter the creek except under very high-flow conditions. The hot spring water has a $\mathrm{Cl}^{-}$concentration of 8,700 ppm and TotHg concentration of $6.9 \mathrm{ppb}$. However, because of its relatively low flow $(0.25 \mathrm{~L} / \mathrm{sec})$, the estimated TotHg flux from this spring is only about $0.055 \mathrm{~kg} / \mathrm{yr}$ (Janik and others, 1994).

In the upper part of the Sulphur Creek watershed, several hot springs and gas vents are present in and adjacent to the Elgin Hg mine. The Elgin hot spring, located within the open cut of the Elgin $\mathrm{Hg}$ mine, has the highest temperature, $67^{\circ} \mathrm{C}$, of all geothermal springs in the Sulphur Creek watershed. The $\mathrm{Cl}^{-}$concentration of the water is $11,400 \mathrm{ppm}$, and the TotHg concentration is $11.0 \mathrm{ppb}$. The flow from the hot spring vent is $1.07 \mathrm{~L} / \mathrm{sec}$, and the estimated TotHg flux is $0.15 \mathrm{~kg} / \mathrm{yr}$ (Janik and others, 1994). Waters from other hot springs adjacent to the Elgin Hg mine have lower Hg concentrations, 0.7 ppb. 


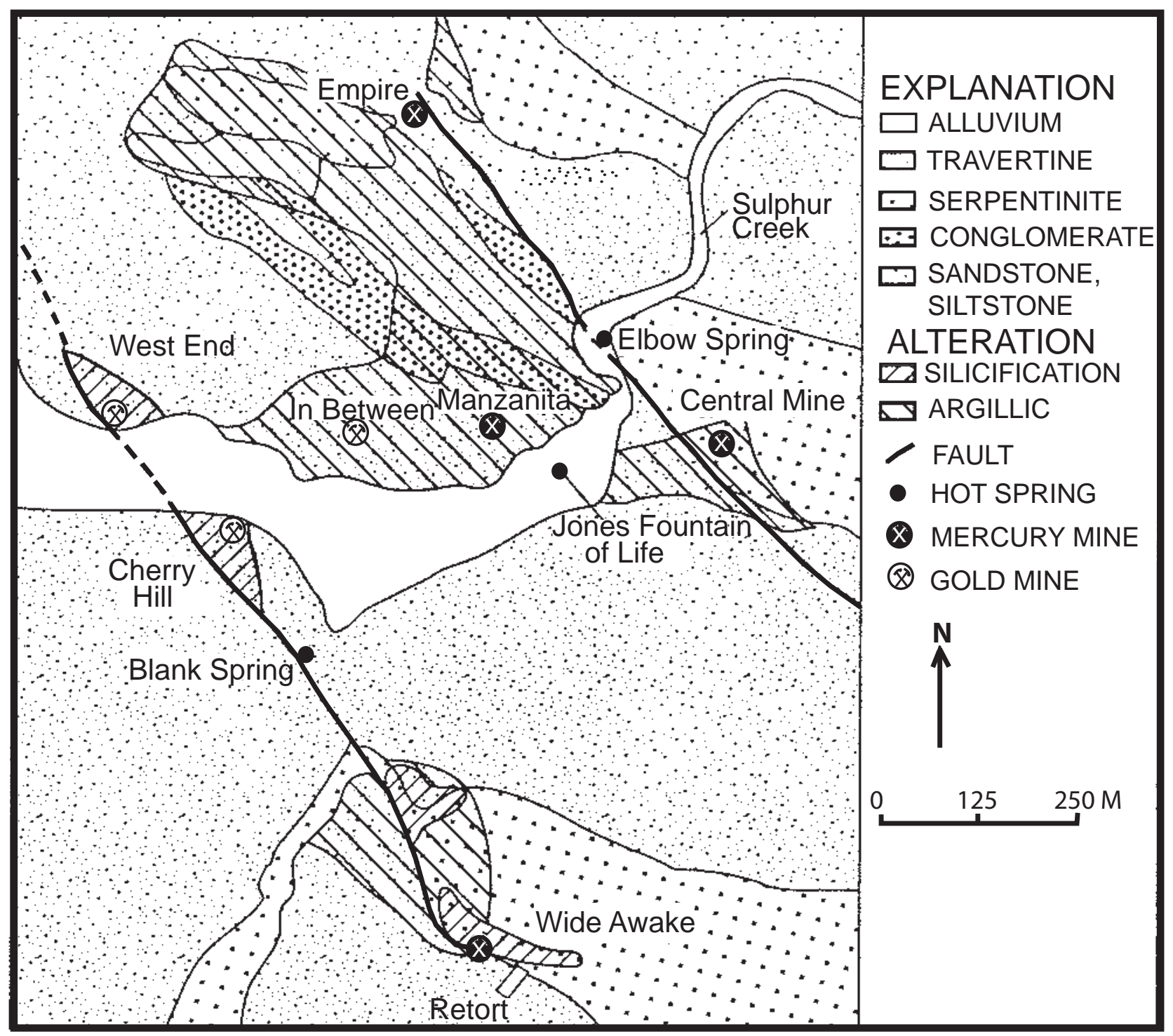

Figure 3. Geology and $\mathrm{Hg}$ and Au deposits located in the Sulphur Creek tributary to Bear Creek. Geothermal springs adjacent to the ore deposits are actively depositing $\mathrm{Hg}$ and $\mathrm{Au}$ and are sources of $\mathrm{Hg}$-enriched sediment to Bear Creek.

All geothermal springs in the Sulphur Creek watershed are elevated in sulfate and sulfide concentration, resulting in $7-16 \times 10^{3} \mathrm{~kg}$ of sulfate being added to Sulphur Creek from these sources per year (Churchill and Clinkenbeard, 2002).

Sulphur Creek water downstream of all geothermal spring inputs has very high concentrations of TotHg, $1.3 \mathrm{ppb}$, 88 percent of which is in the particulate form (Suchanek and others, 2004). The geothermal springs and mine sources in the
Sulphur Creek watershed are significant sources of particulate TotHg to Sulphur Creek, with average estimates ranging from 0.6 to $10.7 \mathrm{~kg} / \mathrm{yr}$ (Suchanek and others, 2004). The relative importance of the $\mathrm{Hg}-\mathrm{Au}$ mine and geothermal $\mathrm{Hg}$ sources in Sulphur Creek has not been sufficiently documented, but under low-flow conditions and low rainfall years, the geothermal Hg source predominates. 


\section{Cold Carbonate Springs}

Cold carbonate springs are present along several faults in the Bear Creek watershed. A large number of these springs are localized along the Bear Fault, which is located to the west of Bear Creek and east of the Rathburn-Petray mines (fig. 4). These springs consist of variable mixtures of meteoric water and saline groundwater derived from connate fluids in sedimentary rocks in the Great Valley sequence. The cold spring waters have a highly variable proportion of saline groundwater, ranging from 13 to 100 percent. Springs along the central part of the Bear Fault have the highest component of saline groundwater and have exceptionally high conductivities $(9,400$ and $19,000 \mu \mathrm{S} / \mathrm{cm})$. The most saline cold spring waters, $6,065 \mathrm{mg} / \mathrm{L} \mathrm{Cl}^{-}$, are comparable to saline geothermal hot spring waters located in the Sulphur Creek watershed. The cold springs are characterized by high concentration of the cations sodium ( $\mathrm{Na}), \mathrm{K}$, rubidium $(\mathrm{Rb})$, lithium (Li), selenium (Se), strontium (Sr), and W, as well as nitrate, sulfate, and DOC. Plots of these cations against $\mathrm{Cl}^{-}$for the various cold springs in the Bear Valley watershed define a two-component linear mixing line, indicating that the spring waters are mixtures of meteoric and saline groundwater. Alkalinity is relatively high in cold carbonate springs and surface waters that drain the Rathburn-Petray mine area. This results from release of carbonate from saline groundwater, and leaching of carbonate from serpentinite and mafic bedrock of the Coast Range ophiolite and the Franciscan Formation. The presence of alkaline $\mathrm{pH}(>8.0)$ indicates that the cold carbonate springs and some surface waters, with a significant component of saline groundwater, are in aqueous equilibrium with calcium carbonate. The alkalinity of spring waters ranges from $2.8 \mathrm{meq} / \mathrm{L}$ as carbonate (less groundwater-dominated) to $29 \mathrm{meq} / \mathrm{L}$ in saline cold spring water that is actively depositing travertine. Bicarbonate is the dominant buffering agent, although organic acids also may buffer these waters.

High concentrations of TotHg, up to $0.7 \mathrm{ppb}$, occur in some cold carbonate springs and saline surface waters that drain the Rathburn-Petray mine area. In cold carbonate spring water, $\mathrm{Hg}$ is present primarily in the filtered fraction, typically comprising from 78 to 100 percent of the TotHg present. In saline surface waters that are dominantly meteoric with a small component of high salinity groundwater, the amount of TotHg in the filtered fraction is highly variable, ranging from 100 percent to less than 4 percent. The concentrations of TotHg in both filtered and unfiltered waters are not correlated with $\mathrm{Cl}^{-}$concentration or any other major or minor element. Processes that control TotHg concentration in saline surface and spring waters are not conservative and may include precipitation and dissolution of carbonate, dissolution of $\mathrm{HgS}$ by DOC, and seasonal changes in surface-water flow. The highest TotHg concentration ( 0.9 ppb measured under dry season low-flow conditions) occurs in surface water from a tributary that drains the north pit of the Petray mine (North fork of Tributary 1 in Slowey and Rytuba, 2008). The water in this tributary is dominantly meteoric $(<1.5$ percent saline groundwater), and the creek sediment has a high concentration of TotHg (350 ppm), which is present as cinnabar and metacinnabar.

\section{Bedrock}

The Hg concentrations in unaltered bedrock exposed in the Bear Creek watershed are typically less than $154 \mathrm{ng} / \mathrm{g}$ (parts per billion $=\mathrm{ppb}$ ), with higher Hg concentrations occurring in sedimentary rocks of the Great Valley sequence being higher in the range of $\mathrm{Hg}$ values (Smith and others, 2008). The Hg concentration in unaltered shales, siltstones, and sandstones in the Great Valley sequence ranges from 31 to $154 \mathrm{ppb}$. Much lower Hg concentrations, less than $24 \mathrm{ppb}$, occur in mafic rocks of the Coast Range ophiolite, serpentinite derived from the ophiolite, and mafic rocks in the Franciscan Formation. The Hg concentration in greywacke, blueschist, and cherty mudstone of the Franciscan Formation ranges from 35 to $88 \mathrm{ppb}$. Volcanic rocks in the Clear Lake volcanic field typically have low Hg concentrations ( $<92 \mathrm{ppb})$. However, volcanic rocks are not present in the Bear Creek watershed, and only minor intrusive basaltic rock has been mapped in the Sulphur Creek watershed. Erosion of hill slopes composed of Great Valley sequence sedimentary rocks would be expected to produce sediment with a $\mathrm{Hg}$ concentration in the range of 30 to $150 \mathrm{ppb}$. Sediment derived from hill slopes composed of Franciscan and Coast Range ophiolite would produce sediment with lower $\mathrm{Hg}$ concentrations, ranging from 20 to $90 \mathrm{ppb}$.

An estimate of the annual TotHg flux of 0.45 to $9.8 \mathrm{~kg}$ from background soils in Sulphur Creek has been calculated by assuming erosion rates between 0.5 and 10 (tons/acre)/yr applied over the entire watershed (Churchill and Clinkenbeard, 2002), but the actual amount of regional background TotHg entering the watershed is unknown. No estimate has been made for the Bear Creek watershed.

\section{Mercury and Gold Mines}

Mines in the Bear Creek watershed include several $\mathrm{Hg}$ and Au mines in Sulphur Creek, and the Rathburn and Petray Hg mines located in the hills (Walker Ridge) on the western side of Bear Valley. All of these Hg mines have had relatively small production, but the surface disturbance and mine wastes at the mines are highly variable. Surface exposures of cinnabar mineralization in the Petray mine open pits have high TotHg concentrations (up to 2,490 ppm) and are a continuing source of Hg-enriched sediment that is released from the mine site resulting in high concentrations of $\mathrm{Hg}$ 


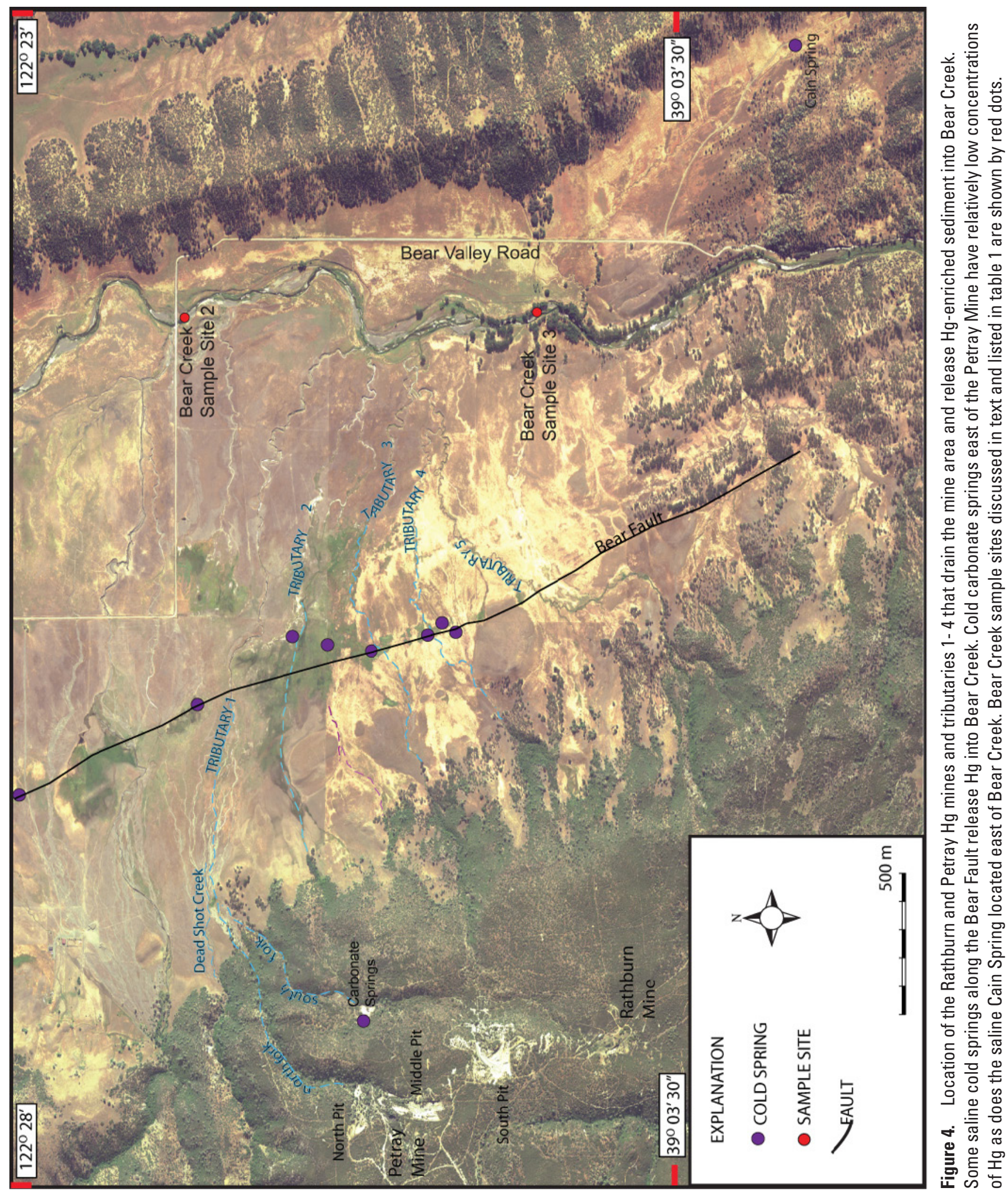


in tributaries that drain the mine area (Slowey and Rytuba, 2008). In Sulphur Creek, erosion of waste rock and tailings from the mine sites is a source of Hg-enriched sediment but Hg-enriched precipitates from geothermal springs located in and adjacent to the mines are likely more significant. Of the 10 major tributaries that enter Bear Creek, Sulphur Creek has the highest sediment $\mathrm{Hg}$ concentrations with $91.8 \mathrm{ppm}$ in the grain size fraction $<63 \mu \mathrm{m}$ (Bosworth and Morris, 2009). In comparison, the other tributaries to Bear Creek have $\mathrm{Hg}$ concentrations in sediment that range from 0.04 to $0.53 \mathrm{ppm}$ in the grain-size fraction $<63 \mu \mathrm{m}$ (Bosworth and Morris, 2009). The average background Hg concentration in sediment within the Cache Creek watershed is $0.06 \mathrm{ppm}$ in the grain size fraction $<63 \mu \mathrm{m}$ (Foe and Bosworth, 2008). Mercury mine tailings (calcines) with TotHg concentrations up to $1,020 \mathrm{ppm}$ are present at only three of the mines. Waste rock containing variable concentrations of TotHg ranging from 10 to $1,020 \mathrm{ppm}$, and Hg-enriched soils ranging in concentration from 10 to $300 \mathrm{ppm}$ are present at all of these mines and are a volumetrically more significant potential source of Hg-enriched sediment to the Bear Creek watershed (Churchill and Clinkenbeard, 2002).

The Manzanita Hg-Au mine and the nearby West End Hg-Au mine and In Between Au prospect (fig. 3) were developed on the periphery of the larger Cherry Hill hot spring $\mathrm{Au}-\mathrm{Hg}$ system that was discovered by Homestake Mining Company in 1977 (Nelson and others, 1993). The mines occur on either side of Sulphur Creek (fig. 3). The Manzanita Au-Hg mine was discovered in 1863 and operated until 1942. Total production was 2,500 flasks of $\mathrm{Hg}$ (U.S. Bureau of Mines, 1965). About 3,000 oz (about $85 \mathrm{~kg}$ ) of Au was produced from the Cherry Hill and Manzanita mines from 1865 to 1891. The $\mathrm{Au}-\mathrm{Hg}$ ores are hosted in silicified shales, sandstones, and conglomerates in the basal section of the Great Valley sequence. Cinnabar is the main Hg-bearing phase, but minor metacinnabar also was present. Where native Au was present, $\mathrm{Hg}$ also occurred as an amalgam (Churchill and Clinkenbeard, 2002). Other sulfides present in the ore included pyrite, marcasite, and stibnite. Bitumen and petroleum occur in some of the gold-quartz veins, especially at the In Between mine. The Manzanita mine workings include several adits and shafts and, in the upper part of the deposit, ores were mined from a glory hole and open cut. Various processing techniques were used at the Manzanita mine. These included stamp mills that introduced $\mathrm{Hg}$ to recover the Au by amalgamation, and mechanical concentration of cinnabar to create a cinnabar concentrate from which $\mathrm{Hg}$ was recovered by a retort (Churchill and Clinkenbeard, 2002). In the 1940s, the Hg concentrates from the mine were processed at the Wide Awake mine, located about $1 \mathrm{~km}$ to the south. There are presently no tailings at the Manzanita, West End, In Between, and Cherry Hill mines. There is a limited amount of waste rock at each of the mine sites, but exposures of altered rock are potential sources of Hg-enriched sediment.
The Central and Empire Hg mines have produced a small amount of $\mathrm{Hg}$ estimated to be about 170 flasks from ores that were processed primarily at the Wide Awake mine. There are small amounts of tailings and waste rock at the Central mine, and waste rock is present around and within a small retort at the Empire mine. The mine site is vegetated and does not appear to be a source of Hg-enriched sediment to Sulphur Creek (Tetra Tech, 2003).

The Wide Awake mine was discovered in the 1870s and produced 1,800 flasks of $\mathrm{Hg}$ until the mine was closed in the 1940s. Some of the production came from ores that were mined at the Manzanita and Empire mines. The Hg ore occurs in the basal section of the Great Valley sequence at the contact between shale and sediments composed of detrital serpentinite. Cinnabar is the main ore mineral and occurs in opalized serpentinite that locally contains abundant petroleum. Mine workings include several surface cuts and underground workings that were accessed by a 152-meter shaft (U.S. Bureau of Mines, 1965). Mercury ores were processed in a 24-ton Scott furnace and several smaller retorts. The pile of tailings that includes some waste rock is estimated to contain 11,000 tons of material (Churchill and Clinkenbeard, 2002) and is a source of Hg-enriched sediment during runoff in the wet season.

The Elgin Hg mine is located in the headwaters of Sulphur Creek, and several hot springs and gas vents are present in and adjacent to the mine workings. The mine was discovered in the early 1870s, and only a small amount of production, about 50 flasks, has been reported for the mine. The Hg ores occur along the contact of serpentinite and shale of the Great Valley sequence and are hosted in silicified serpentinite and in acid-leached serpentinite in the upper part of the ore body. Cinnabar is the primary ore mineral, and native sulfur occurs in the acid-leached part of the ore body. Pyrite is present in the lower part of the ore body. The mine workings consist of surface cuts, adits, and underground workings that were limited in development because the hot springs and associated sulfur and methane gases precluded extensive underground mining (U.S. Bureau of Mines, 1965). The small amount of ore was processed in a retort, and the amount of tailings on the mine site is minor, but waste rock in the open cuts is a potential source of Hg-enriched sediment. The Elgin hot spring vents in the central part of the main open cut, and effluent from the spring is collected in a small pond. A black precipitate that is enriched in $\mathrm{Hg}$ forms in the hot spring vent and collects in the pond but is only released to the watershed under high flows.

The Clyde Au mine (fig. 1) ore body was discovered in the early 1860s and has produced a small amount of Au. Native Au and pyrite occur in a silicified body of serpentine. The Au was recovered in a mill that apparently did not use Hg; more recent reprocessing of the tailings used gravity separation rather than $\mathrm{Hg}$ to recover the $\mathrm{Au}$. This mine has only a small potential to release Hg-enriched sediment into Sulphur Creek. 
Estimates of yearly TotHg flux from mine wastes into Sulphur Creek have been based on estimates of erosion rates from mine wastes with known $\mathrm{Hg}$ concentrations. The $\mathrm{Hg}$ flux into Sulphur Creek is estimated to range from 4.4 to $18.6 \mathrm{~kg}$, while the range of $\mathrm{Hg}$ flux into Bear Creek is from 0.7 to $23.5 \mathrm{~kg}$ (Churchill and Clinkenbeard, 2002). However, there is high uncertainty in these estimates and only very limited data are available to quantify the $\mathrm{Hg}$ flux from the mine sites. Only two samples of water from the intermittent creek that drains the Wide Awake mine area have been collected, and the data indicate significant release of $\mathrm{Hg}$ from the mine site during the wet season. The concentration of TotHg in water from the Wide Awake mine drainage measured in February 2000 and 2001 was 2.5 and $4.3 \mathrm{ppb}$ respectively, and from 52 to 58 percent of the TotHg was in the filtered fraction (Suchanek and others, 2004).

The Rathburn Hg mine ore body was discovered and initially mined in the early 1890s. The Rathburn and the more recently developed Petray open pit mines are localized along fault zones in serpentinite that has been altered and cut by quartz and chalcedony veins. Cinnabar is the primary ore mineral, and metacinnabar has been identified in sediment derived from the Petray mine. The Hg ores formed in a hot spring system in the steam-heated environment present above boiling groundwater table. However, no active hot springs are present in the deposits. The Rathburn Hg mine is relatively small, having produced 100 flasks of $\mathrm{Hg}$. Mining in the late 1960s and early 1970s recovered about 400 flasks of $\mathrm{Hg}$ from the Petray open pit mine (U.S. Bureau of Mines, 1965). At the Rathburn Mine, Hg ores were processed in a brick retort, and small amounts of calcines are present that contain up to 1,020 ppm Hg (Churchill and Clinkenbeard, 2002; Slowey and Rytuba, 2008). Waste rock derived from open cuts (in altered serpentinite) contains less than $39 \mathrm{ppm}$ TotHg. Ores from the Petray Mine were processed offsite in a rotary furnace at the Abbott Mine, and, as a result, there are no mine tailings at the Petray mine. However, waste rock and ore in altered serpentinite are sources of Hg-enriched sediment that are released from the mine during storm events. The Hg concentration in sediments of the two tributaries that drain the Petray mine is highly elevated for the sampled section extending $2 \mathrm{~km}$ from the mine site. Both cinnabar and metacinnabar are present in sufficient quantity to be panned easily from the sediment (Slowey and Rytuba, 2008). The relative importance of Hg-enriched sediment released from the Rathburn and Petray mines as compared with $\mathrm{Hg}$ released from cold carbonate springs along the Bear Fault has not been determined, but both sources contribute $\mathrm{Hg}$ to Bear Creek (Slowey and Rytuba, 2008). Sediment in Bear Creek just downstream of the input from tributaries that drain the Rathburn and Petray mines (Monitoring Site 3, table 1) has a highly elevated TotHg concentration, 9,290 ppb. The TotHg concentration in Bear Creek sediment is considerably lower, $80 \mathrm{ppb}$, upstream of the Rathburn and Petray input (Monitoring Site 2, table 1), which indicates a significant $\mathrm{Hg}$ release from the mine sites. Although the TotHg concentration in Bear Creek water downstream of the Rathburn and Petray mine input under low-flow conditions is very low $(2.2 \mathrm{ng} / \mathrm{L}$; pptr $=$ parts per trillion), it is still higher than in water upstream of the mine input, which has a TotHg concentration of 0.45 pptr.

\section{Mercury Assessments in the Bear Creek Watershed}

\section{Physical/Chemical Assessments}

Water samples were collected during 2000-2001 from a number of sites within the Cache Creek watershed and analyzed for TotHg and monomethyl Hg (MMeHg) (Domagalski and others, 2004; Slotton and others, 2004; Suchanek and others, 2004). A subset of those sites was within the Bear Creek Watershed and their locations are identified below.

\section{Upper Bear Creek}

This site is located at the Bear Valley Road bridge crossing (N: 39 $\left.{ }^{\circ} 5.83^{\prime}, \mathrm{W}: 122^{\circ} 24.71^{\prime}\right)$. This site was believed to be upstream of all known mine loading of $\mathrm{Hg}$, and it is located upstream of the Hg inputs into Bear Creek identified by Slowey and Rytuba (2008). Results from Slotton and others (2004) collections are presented below. For both unfiltered and filtered aqueous TotHg and MMeHg, the Upper Bear Creek site exhibited concentrations that were among the lowest in the entire Cache Creek and Bear Creek watersheds. At the Upper Bear Creek site, unfiltered aqueous TotHg ranged from ca. 0.5 to $4.0 \mathrm{pptr}$ and filtered aqueous TotHg ranged from ca. 0.4 to 1.0 pptr, respectively. These data suggest that the TotHg at this site is mostly associated with particles. $\mathrm{MMeHg}$ in unfiltered aqueous samples ranged from ca. 0.05 to $0.11 \mathrm{pptr}$ and filtered aqueous samples ranged from ca. 0.02 to $0.10 \mathrm{pptr}$, suggesting that a large proportion of $\mathrm{MMeHg}$ is found in the dissolved form. Because the Upper Bear Creek site is upstream of all known mining sites, these results could indicate a geothermal or saline spring (as opposed to a mining source) as the primary source of both TotHg and MMeHg in this region of Bear Creek.

\section{Sulphur Creek}

This site, located in Sulphur Creek upstream of the confluence with Bear Creek (N: 39 2.21', W: $122^{\circ} 24.56^{\prime}$ ), represents $\mathrm{Hg}$ inputs from $\mathrm{Hg}$ mines, Au mines, and geothermal springs along Sulphur Creek. Data from Slotton and others (2004) on aqueous TotHg and MMeHg in Sulphur Creek demonstrate a different result in comparison with the Upper Bear Creek site. Unfiltered and filtered TotHg ranged from ca. 0.3 to $1.1 \mathrm{ppb}$ and from ca. 0.09 to $0.3 \mathrm{ppb}$, respectively, suggesting that at this site, the largest component of TotHg is found in the particulate form, not in the dissolved 
form. MMeHg ranged from ca. 0.2 to 20 pptr in unfiltered samples and from ca. 0.09 to $1.5 \mathrm{pptr}$ in filtered aqueous samples, again suggesting a significant component derived from particulate MMeHg. Although there are several large geothermal springs in and along Sulphur Creek, numerous adjacent $\mathrm{Hg}$ and $\mathrm{Au}$ mines erode into Sulphur Creek. Thus, although the dissolved fraction of both TotHg and MMeHg derived from the geothermal springs likely contribute significantly to $\mathrm{Hg}$ loading into Sulphur Creek, the particulate $\mathrm{Hg}$ found in the eroding soils from the surrounding mines likely overwhelms the contribution from the springs.

Within Sulphur Creek, Suchanek and others (2004) also analyzed unfiltered water collected during February 2000 and 2001. These data indicated that the highest TotHg concentrations were extremes observed from geothermal spring sites as follows: (1) The Jones Fountain of Life spring: $24.3 \mathrm{ppb}$ in 2000 and $39.7 \mathrm{ppb}$ in 2001, and (2) geothermal springs from which the Wilbur Hot Springs Resort draws hot water for their baths at 4.0-7.3 ppb in 2001. However, TotHg concentrations immediately downstream of the Resort at the USGS gaging station (Sulphur Creek Index Station) were considerably reduced to $1.0 \mathrm{ppb}$ (90 percent of which was in particulate form) in 2000 and $1.3 \mathrm{ppb}$ (88 percent of which was in particulate form) in 2001.

\section{Middle Bear Creek Downstream of Sulphur Creek}

This site, located about $10 \mathrm{~km}$ downstream of the confluence of Sulphur Creek (at approximately Monitoring Site 9 on fig. 1) (N: 38 $58.88^{\prime}$, W: $\left.122^{\circ} 20.94^{\prime}\right)$, represents a reach of Bear Creek that has approximately 10 -fold dilution of Sulphur Creek inputs. Bear Creek exhibits TotHg and MMeHg concentrations that are intermediate between the Upper Bear Creek site and the Sulphur Creek site. TotHg in unfiltered and filtered aqueous samples exhibited ranges from ca. 11 to $150 \mathrm{pptr}$ and from ca. 8 to $40 \mathrm{pptr}$, respectively. MMeHg in unfiltered and filtered aqueous samples exhibited ranges from ca. 0.2 to 1.5 pptr and from ca. 0.09 to $0.5 \mathrm{pptr}$, respectively. The distribution of these ranges of TotHg and MMeHg with respect to the proportions represented by filtered and unfiltered (that is, dissolved vs. particulate) components suggest a mixture of contributions between dissolved and particulate sources. This interpretation would be consistent with the multiple sources influencing the composition of the water mass at a site $10 \mathrm{~km}$ downstream of the confluence of Sulphur Creek with Bear Creek. Data on TotHg and MMeHg from the Upper Bear Creek site suggested contributions from a source that is primarily in a dissolved form. This source water would then be mixed with a Hg source that was primarily particulate from Sulphur Creek. As particulate material from the Sulphur Creek source is deposited downstream along the Bear Creek streambed, the influence of particulate $\mathrm{Hg}$ diminishes, consistent with the greater overlap in the ranges of $\mathrm{Hg}$ in filtered and unfiltered samples for both TotHg and MMeHg.

A visual analysis of time-series data for TotHg and MMeHg at the Middle Bear Creek site from January 2000 to September 2001 revealed that TotHg peaks occurred during the winter rainy season (February) when maximum erosion typically would send Hg-laden particles downstream. MMeHg peaks at this site occurred during the summer (July/August) both years. A further analysis of the MMeHg:TotHg ratios ${ }^{1}$ for water samples at these three sites reveals that this ratio is highest for the Upper Bear Creek site ( 0.1 for unfiltered water; 0.05 for filtered water), lowest for the Sulphur Creek site ( 0.001 for unfiltered water; 0.002 for filtered water), and intermediate for the Middle Bear Creek site ( 0.01 for unfiltered water; 0.01 for filtered water).

\section{Biological Assessments}

Several types of bacteria can convert naturally occurring inorganic $\mathrm{Hg}$ to its more toxic form, $\mathrm{MMeHg}$, which is a neurotoxin and mutagen. MMeHg may affect several physiological functions, including vision, response to stimuli, growth, and reproduction in both vertebrates and invertebrates. In some cases, $\mathrm{MMeHg}$ can cause mortality. The effects of $\mathrm{Hg}$ toxicosis are exhibited most prominently in the egg or fetal stage, but may affect juvenile and adult stages as well. Thus, it is important to understand what concentrations of $\mathrm{Hg}$ are present, and evaluate whether corrective measures are feasible to lessen the impacts of $\mathrm{Hg}$ to wildlife and humans in this region.

Wildlife resources of significance in the Bear Creek watershed include wintering bald eagles (Haliaetus leucocephalus), prairie falcons (Falco mexicanus), greater roadrunner (Geococcyx mexicanus), tule elk (Cervus elaphus nannodes), river otters (Lontra canadensis), and foothill yellow-legged frogs (Rana boylii) (Schwarzbach and others, 2001; Bureau of Land Management, 2004). An estimated 154 bird species have been documented in the watershed (Bureau of Land Management, 2004). BLM recognizes several sensitive species found in the watershed, including: Townsend's western big-eared bat (Plecotus townsendii), Pallid bat (Antrozous pallidus), burrowing owl (Athene cunicularia), St. Helena mountain king snake (Lampropeltis zonata zonata), foothill yellow-legged frog, and western pond turtle (Actinemys marmorata), and 17 sensitive plant species. Two of these species, foothill yellow-legged frog and the western pond turtle, are California Species of Special Concern (Jennings and Hayes 1994; California Department of Fish and Game, 2009).

\footnotetext{
${ }^{1} \mathrm{MMeHg}$ :TotHg ratios typically are regarded as a proxy for $\mathrm{MMeHg}$ bioavailability.
} 


\section{Invertebrates}

Beginning in April 1995, Slotton and others (1997) conducted a survey of TotHg in benthic stream invertebrates at 38 sites along Cache Creek and the Bear Creek watershed (figs. 5, $\underline{6}, \underline{7})$. This survey involved collections of several trophic levels of benthic invertebrates including: Ephemerellidae (mayflies - herbivores), Siphlonuridae (swimming mayflies - herbivores), Hydropsychidae (netspinning caddisflies - drift feeders), Pteronarcidae (giant stoneflies - leaf shredders), Perlodidae (yellow sally stoneflies - small predators), Calopterygidae (damselflies - small predators), Sialidae (alderflies - small predators), Naucoridae (creeping water bugs - large predators), Aeshnidae (dragonflies - large predators), Libellulidae (dragonflies large predators), Tipulidae (craneflies - large predators), and Corydalidae (hellgrammites - large predators).

Slotton and others (1997) found significant variability in the concentration of TotHg in invertebrate tissues among different sites within the Cache Creek watershed with a range of about $0.05-22.74 \mu \mathrm{g} / \mathrm{g}$ (parts per million = ppm) dry weight (dw). The highest TotHg concentrations were obtained from Harley Gulch at Highway 20 (up to 22.74 ppm, dw) and within Sulphur Creek (up to $2.69 \mathrm{ppm}, \mathrm{dw}$ ) (note asterisks in fig. 6). Upstream of the confluence with Sulphur Creek, Bear Creek invertebrate whole body TotHg typically ranged from about 0.1 to $0.2 \mathrm{ppm}(\mathrm{dw}$ ) but as soon as Sulphur Creek waters enter Bear Creek, invertebrate TotHg concentrations increased to about 1.2-1.5 ppm (dw). However, one site about $0.4 \mathrm{~km}$ upstream of the confluence of Sulphur Creek with Bear Creek had elevated invertebrate TotHg concentrations to about $0.3 \mathrm{ppm}(\mathrm{dw})$. Although this increase appears to be real, it is from a single site at a single sampling point in time and its significance should not be over-interpreted. It is possible that there are additional Hg sources entering Bear Creek upstream of the confluence of Sulphur Creek, possibly from the Rathburn-Petray mine area described above. In addition, roadbed materials and/or grazing effects in Bear Valley could affect Hg concentrations upstream of Sulphur Creek. Schwarzbach and others (2001) also sampled invertebrates in Bear Creek near Hamilton Canyon, about $1.2 \mathrm{~km}$ upstream of the Slotton site, and found TotHg concentrations ranging from 0.02 to $0.04 \mathrm{ppm}$, ww (about $0.10-0.20 \mathrm{ppm}, \mathrm{dw}$ ).

Further studies conducted from 1999 to 2003 by Slotton and others (2004) provided additional Hg data from water, invertebrates, and fish (where present) at three sites in the Bear Creek watershed (in addition to other sites along the entire Cache Creek watershed). Their findings mirror the relative ranges of TotHg and $\mathrm{MMeHg}$ found in aqueous samples presented in section, "Physical/Chemical Assessments.” Average TotHg in aquatic insects ranged from ca. 19-41 ppb, wet weight (ww) at the Upper Bear Creek site to ca. 168-465 ppb (ww) at the Middle Bear Creek site, and ca. 416-1,987 ppb (ww) at the Sulphur Creek site. MMeHg ranged from ca. 18-33 ppb (ww) at the Upper Bear Creek site, to ca. 138-359 ppb (ww) at the Middle Bear Creek site, and ca. 139-290 ppb (ww) at Sulphur Creek. Interestingly, the proportion of MMeHg in these samples was lowest (17-33 percent) at the Sulphur Creek site, intermediate at the Middle Bear Creek site (66-84 percent), and highest at Upper Bear Creek (81-97 percent). A visual analysis of time-series data for $\mathrm{MMeHg}$ concentrations in these invertebrates at the Middle Bear Creek site exhibited trends similar to water, with MMeHg peaks occurring during the summer (July/August) both years. That same analysis at the Upper Bear Creek site was not as conclusive, but exhibited a maximum in $\mathrm{MMeHg}$ during the summer of 2001 only.

Schwarzbach and others (2001) also analyzed aquatic insects (e.g., Trichoptera, Zygoptera, Anisoptera, and Megaloptera) in Bear Creek as well as other locations within the Cache Creek watershed. Their data revealed a pattern of lower TotHg concentrations ( $<0.5 \mathrm{ppm} \mathrm{dw}$ ) in the North Fork of Cache Creek, Mill Creek, and Bear Creek upstream of Sulphur Creek, but much higher concentrations at sites in Bear Creek downstream of Sulphur Creek (0.5-5.2 ppm dw) and in Sulphur Creek proper (5.0-8.7 ppm dw). In general, their results agreed with those of Slotton and others (1997) for comparable taxa and sites.

\section{Fish}

Slotton and others (2004) focused their fish Hg analyses from their wider Cache Creek watershed study primarily on California roach (Hesperoleucus symmetricus), speckled dace (Rhinichthys osculus), and red shiner (Notropis lutrensis), all three of which exhibited average MMeHg concentrations as a percentage of TotHg of 90 percent or greater. However, only California roach were abundant enough within the Bear Creek watershed to obtain sufficient samples to analyze trends. No fish were found in Sulphur Creek. However, an analysis of the MMeHg:TotHg ratio was conducted on California roach from Upper Bear Creek and Middle Bear Creek. Upper Bear Creek roach $(\mathrm{N}=29)$ exhibited a MMeHg percentage of 97.66 percent, whereas the roach at the downstream site, Middle Bear Creek ( $\mathrm{N}=31$ ), yielded a MMeHg percentage of 86.77 percent. These results are similar to those from analyses on water and invertebrates from those same sites. Time-series data for California roach at the Upper Bear Creek site and the Middle Bear Creek site demonstrated MMeHg peaks in summer June/July/August time periods for both 2000 and 2001.

Schwarzbach and others (2001) also collected California roach from Bear Creek sites upstream and downstream of the confluence with Sulphur Creek in April and August 1997. Results were consistent with Slotton and others (2004), with TotHg concentrations in roach that were significantly higher downstream than upstream of the confluence with Sulphur Creek: 3 times greater in April (upstream $=0.1 \mathrm{ppm}$, ww; downstream $=0.3 \mathrm{ppm}$, ww) and 4 times greater in August (upstream $=0.4 \mathrm{ppm}$, ww; downstream $=1.7 \mathrm{ppm}$, ww). Sacramento pikeminnows (Ptychocheilus grandis) also were collected in Bear Creek in 1998 and exhibited the highest TotHg concentrations among all pikeminnows from a total of five sites throughout the entire Cache Creek watershed. 


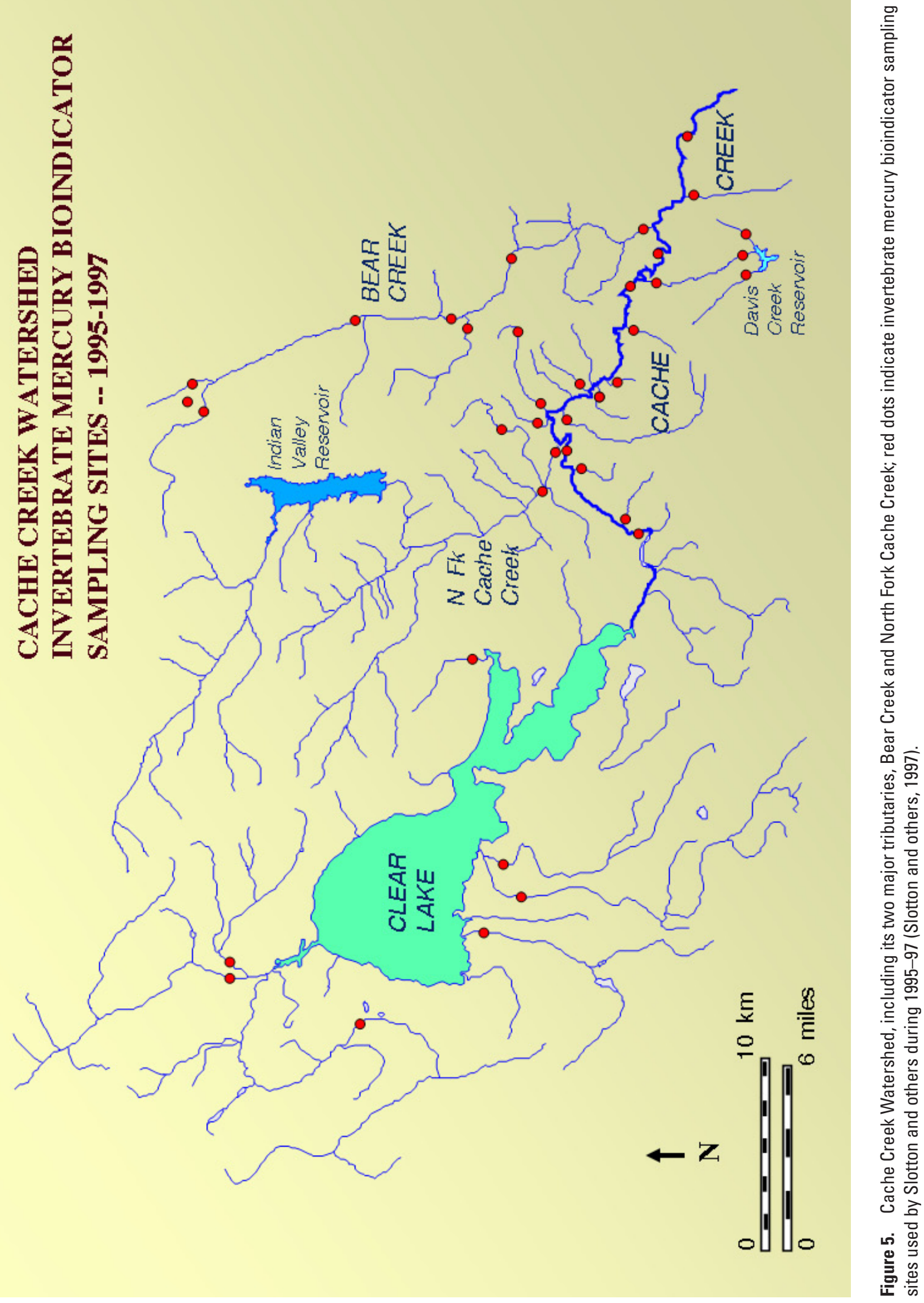




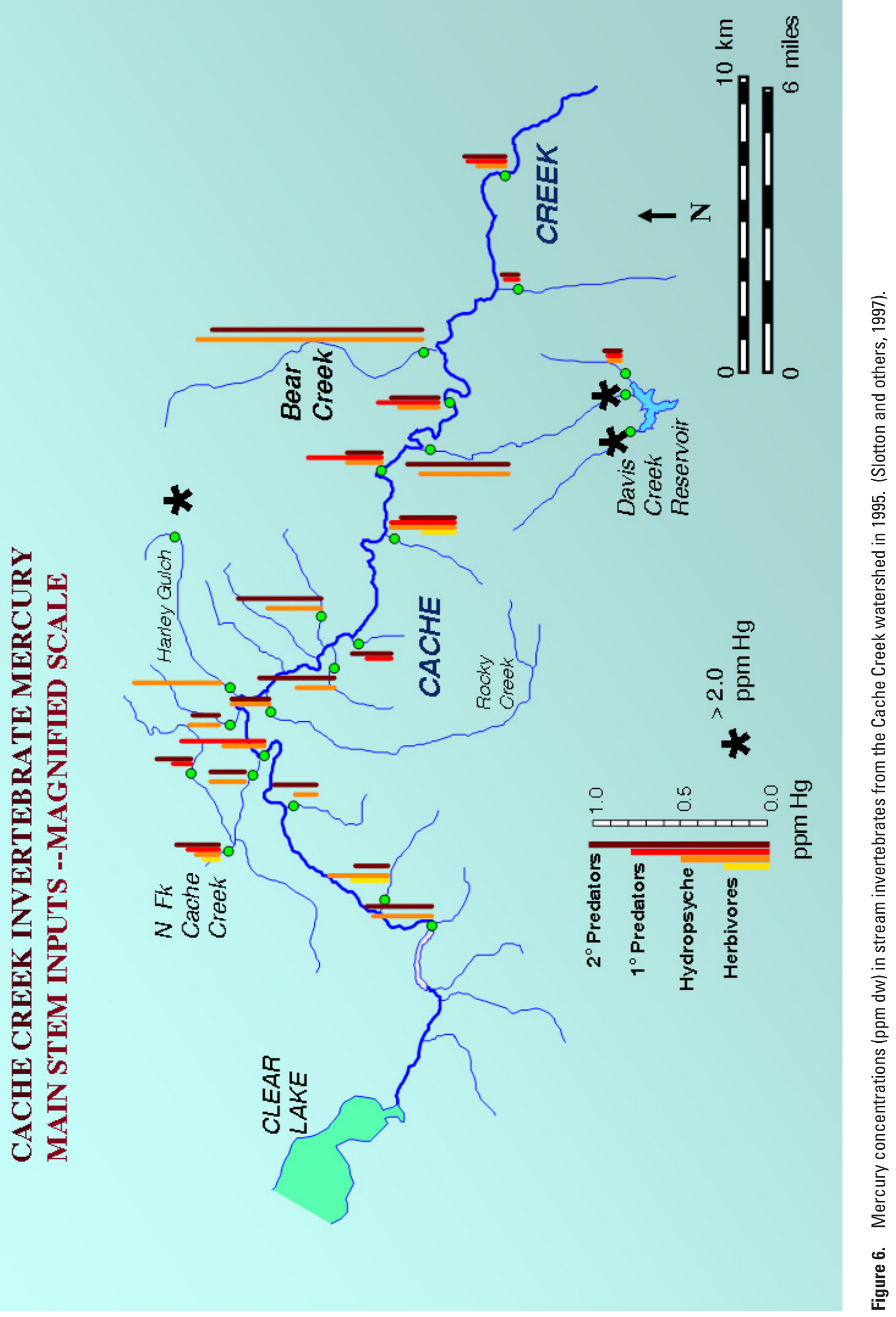




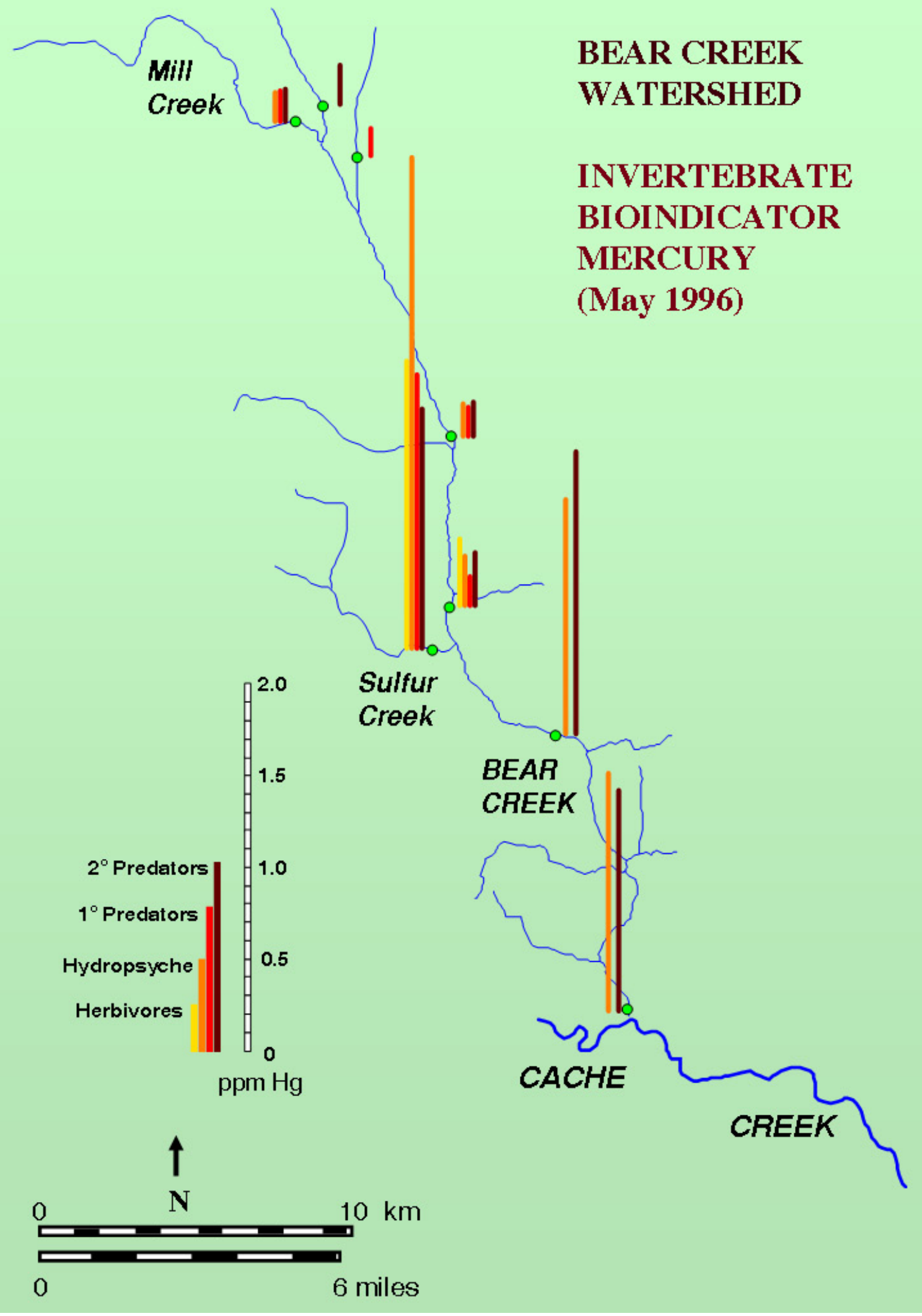

Figure 7. Mercury (ppm dw) in stream invertebrates in the Bear Creek Watershed from D. Slotton collections in 1996 (Slotton and others, 1997). 


\section{Amphibians and Birds}

Schwarzbach and others (2001) collected six foothill yellow-legged frogs (Rana boylii) from Bear Creek, three from upstream, three from downstream of the Sulphur Creek confluence, and a sample from Bear Creek at Highway 20. The range of TotHg concentrations was 0.075-0.538 ppm (ww) with the highest value obtained at the Highway 20 site. The mean TotHg was $0.11 \mathrm{ppm}(\mathrm{ww})$ in upstream samples and $0.31 \mathrm{ppm}(\mathrm{ww})$ in downstream samples.

At 22 sites in 1997 and 19 sites in 1998, Hothem and others (in press) collected and analyzed TotHg in three anuran species from the Cache Creek watershed, including sites within the Bear Creek watershed: American bullfrogs (Lithobates catesbeianus), Foothill yellow-legged frogs (Rana boylii), and Pacific chorus frogs (Pseudacris sierra). Results were comparable between 1997 and 1998. Pooling data for both years, the geometric means for TotHg in Bear Creek bullfrogs in 1997 were 0.032-0.390 ppm (ww) at sites upstream of Sulphur Creek and 0.423-0.561 ppm (ww) for sites downstream of Sulphur Creek. For yellow-legged frogs, the pattern was similar; using pooled data, TotHg ranged from 0.082 to $0.159 \mathrm{ppm}$ (ww) upstream of the confluence with Sulphur Creek, and 0.328 to $0.846 \mathrm{ppm}$ (ww) downstream of Sulphur Creek. Similarly, Pacific chorus frog TotHg at a single site was $0.166 \mathrm{ppm}$ (ww) upstream of Sulphur Creek and 0.258 ppm (ww) downstream of Sulphur Creek.

In 1997, Schwarzbach and others (2001) collected and analyzed three killdeer (Charadrius vociferus) eggs from separate nests in the Bear Creek region. One from a nest near the Jones Fountain of Life yielded a TotHg concentration of $0.26 \mathrm{ppm}$ (ww) and eggs from two nests on Bear Creek ca. $0.4 \mathrm{~km}$ downstream of the Sulphur Creek confluence contained TotHg concentrations of 0.10 and $0.90 \mathrm{ppm}$ (ww).

Hothem and others (2008) reported TotHg concentrations from cliff swallow (Petrochelidon pyrrhonota) eggs and nestling carcasses collected in 1997 and 1998 from nests within the Cache Creek watershed, including the Bear Creek watershed. Geometric mean values for egg TotHg ranged from 0.02 to $0.04 \mathrm{ppm}(\mathrm{ww}$ ) at a reference site upstream of the confluence of Sulphur Creek, 0.097-0.208 ppm (ww) at Sulphur Creek sites and 0.070-0.118 ppm (ww) for Bear Creek sites downstream of the Sulphur Creek confluence. TotHg geometric means in nestling carcasses ranged from $0.047 \mathrm{ppm}(\mathrm{ww})$ at a reference site upstream of the Sulphur Creek confluence to $0.116 \mathrm{ppm}$ (ww) downstream of the confluence.

\section{Overview of Historical Data}

Cumulative data for water, invertebrates, and fish matrices show similar patterns of minimum TotHg and MMeHg concentrations at the Upper Bear Creek site, maximum concentrations at the Sulphur Creek site (no fish data available for Sulphur Creek), and intermediate concentrations downstream of the confluence of Sulphur Creek with Bear Creek at the Middle Bear Creek site. In addition, the ratio of MMeHg:TotHg (or the percentage of TotHg as $\mathrm{MMeHg}$ ) exhibited similar trends for all matrices; i.e., the highest ratios were found at the Upper Bear Creek site, the lowest ratios at Sulphur Creek, and intermediate ratios at the Middle Bear Creek site (Slotton and others, 2004). As discussed above, because no known mining sites are located near or upstream of the Upper Bear Creek site, the Hg source influencing this site is most likely a geothermal spring, which could easily be undetected if it lies within the stream bed itself. In addition, evidence from the Sulphur Creek site suggests that the $\mathrm{Hg}$ source for that site is dominated by $\mathrm{Hg}$ mines.

Several recent publications provide evidence that cinnabar and/or metacinnabar, the primary forms of $\mathrm{Hg}$ at Hg mines, are more refractory and less bioavailable than other forms of $\mathrm{Hg}$ (Kim and others, 2000; Bloom and others, 2003; Suchanek and others, 2008b). Thus, the Bear Creek watershed data also are consistent with an interpretation that $\mathrm{Hg}$ derived from springs is more bioavailable and thus could be bioaccumulated more efficiently than $\mathrm{Hg}$ derived from mining sources. That is, despite the absolute concentrations of $\mathrm{Hg}$, if the primary source of $\mathrm{Hg}$ at the Upper Bear Creek site is primarily from springs (see discussions above for water), and the primary source of $\mathrm{Hg}$ at Sulphur Creek was mining (see discussion above for water), this would result in a higher proportion of $\mathrm{MMeHg}$ to TotHg in water, invertebrates and fish from the Upper Bear Creek site (which may derive its $\mathrm{Hg}$ from springs), a lower proportion of MMeHg:TotHg at the Sulphur Creek site (which is dominated by mines), and an intermediate proportion at the Middle Bear Creek site (which has a mixture of the two types of sources). Therefore, sites having geothermal or saline spring influence may play a relatively more significant role in producing $\mathrm{MMeHg}$ than those sites dominated by mines. For example, even though the absolute amount of TotHg at the Upper Bear Creek site is quite low, the amount of MMeHg produced per unit of TotHg is greatest at this site (likely dominated by $\mathrm{Hg}$ sources from springs) and lowest at Sulphur Creek (likely dominated by $\mathrm{Hg}$ sources from mining).

Domagalski and others (2004) estimated annual TotHg loading from Bear Creek as well as Sulphur Creek in relation to their contributions to the water discharges of the Cache Creek watershed and the Yolo Bypass for water years 2000 and 2001. Interestingly, Sulphur Creek contributed ca. 1.8-2.8 $\times 10^{6} \mathrm{~m}^{3}$ annually (representing ca. 1-2 percent of the total flow of downstream Cache Creek) and Bear Creek contributed ca. 18.3-33.3 × $10^{6} \mathrm{~m}^{3}$ annually (representing ca. $12-19$ percent of the total flow of downstream Cache Creek). 


\section{Mercury Monitoring Protocol}

\section{Objective}

The objective of this monitoring protocol is to document procedures for collecting and processing water, sediment, and biota for estimation of TotHg and MMeHg in the Bear Creek watershed. Concurrent sampling of TotHg and $\mathrm{MMeHg}$ in biota as well as water and sediment will provide information regarding the relative bioavailability of $\mathrm{Hg}$ released from $\mathrm{Hg}$ sources in the watershed and identify environments of $\mathrm{Hg}$ methylation.

These protocols will assist landowners, land managers, water-quality regulators, and scientists in detecting whether restoration/mitigation actions lead to significant progress toward achieving water-quality goals to reduce $\mathrm{Hg}$ in Bear Creek and Sulphur Creek to meet total maximum daily load (TMDL) standards established by the Central Valley Regional Water Quality Control Board (CVRWQCB).

\section{Sampling}

Water, sediment, and biota should be sampled for a minimum of 2 years before any remediation activity (Pre-R). Because of potentially significant inter-annual variability in precipitation events that drive erosion of Hg-laden sediments from the landscape into streams within the Bear Creek watershed, as well as inter-annual variability in the production of $\mathrm{Hg}$-charged fluids from cold or hot springs, at least 2 years is needed to provide adequate baseline data prior to the commencement of remediation. However, if time and funding allow, it would be advantageous to collect Pre-R data for up to 5 years to confirm trends from past studies. Following remediation, water, sediment, and biota should be sampled for several years (Post-R). For a number of reasons, including the physical disturbance effects of remediation, reduction in loading, the inter-annual variability factors discussed above, and changes in bioaccumulation rates, it is unknown how long it will be before potential changes in Hg concentrations occur in abiotic and biotic matrices after remediation. Therefore, the length of time needed to detect changes will most likely be longer than the time needed to establish a reliable baseline. Up to 10 years of Post-R sampling would be desirable to account for those factors identified above. At a minimum, Post-R sampling should be conducted for 5 years. If additional remediation projects are begun or completed during the initial Post-R phase, then the sampling plan should revert to the Pre-R protocol, which would start a new Post-R phase after that subsequent remediation was completed.

\section{Seasonality}

Summer (June-August) appears to be the season when MMeHg production reaches a maximum at all sites within the Bear Creek watershed as evidenced by data from water, sediments, invertebrates, and fish. During Pre-R monitoring, water, sediment, and biota should be sampled in the spring and late summer/early fall and analyzed for TotHg and MMeHg. This would serve two purposes. First, it would provide information to assess what concentrations of TotHg and $\mathrm{MMeHg}$ are present in spring during typical breeding periods for many wildlife species. Second, it would confirm that late summer/early fall is a period of higher MMeHg concentrations (based on data from previous studies). If these results are consistent with data from previous studies, water, sediment, and biota could be collected only in the late summer in subsequent Pre-R years. During Post-R years for any of the mine sites in the watershed, water, sediment, and biota should be collected in the spring and late summer and analyzed for both TotHg and MMeHg. If these results also are consistent with previous data, water, sediment, and biota could be collected only in the late summer.

\section{Physical/Chemical Matrices}

Based on existing data, and the need to identify potential changes in Hg loading and bioaccumulation in relation to remediation actions, we recommend 10 monitoring sites for physical and biological matrices (table 1). Sampling sites for the Bear Creek watershed were selected based on spatial relationships to known natural and anthropogenic sources of Hg within the watershed (fig. 1), and the justification for each sample site is provided in table 1 . The frequency and timing of water and sediment sampling should be coordinated with biota sampling. All samples at a site should be collected on the same day during similar flow and weather conditions in the watershed. It is important that water and sediment samples be collected prior to biota sampling to avoid any changes in water quality that arise from disturbance of the stream during biota collection. Water should be collected for analysis of TotHg and $\mathrm{MMeHg}$ in unfiltered and filtered samples. Sediment should be collected for analysis of TotHg and MMeHg. The unfiltered water sample provides information on TotHg and $\mathrm{MMeHg}$ associated with particulate phases in the water. The filtered water sample provides information on $\mathrm{Hg}$ that is dissolved as well as TotHg and MMeHg present in colloids that pass through a $0.45-\mu \mathrm{m}$ filter (Babiarz and others, 2001). Based on results from historical studies (see above), late summer to early fall appears to be the season during which maximum $\mathrm{MMeHg}$ concentrations were observed in water, sediments, and biota. Because this is the most critical toxic form of $\mathrm{Hg}$ 
in this system, it is advisable that samples be collected during periods when MMeHg is highest in order to relate results to impacts on biota. However, it is possible that different weather or precipitation conditions from those that were present during the previous studies could alter the seasonality of maximum MMeHg. Therefore, some sampling at other seasons (for example, spring) should be incorporated into this monitoring plan. In order to relate physical/chemical data to biological data, it is recommended that for the first 2 years, physical/ chemical data be collected in both spring and late summer/ early fall.

Episodic transport of TotHg and MMeHg caused by high flows associated with storm events has been documented for several watersheds (Babiarz and others, 1998; Hurley and others, 1998; Scherbatskoy and others, 1998; Balogh and others, 2005). Because most Hg transported in a watershed moves during a few high-flow events, it also is necessary to sample Bear Creek during at least one high-flow event per year in order to monitor $\mathrm{Hg}$ dynamics in stream water and assess $\mathrm{Hg}$ transport from both natural and mine impacted areas.

\section{Sample Collection and Processing}

Water and sediment should be collected using standard ultra-clean sampling and handling protocols (Gill and Bruland, 1990; Bloom, 1995) to avoid introduction of extraneous $\mathrm{Hg}$ into the samples. Sampling personnel must wear clean, nonpowdered gloves made of polyethylene, latex, or PVC at all times when handling sampling equipment and containers, and gloves must be changed between sample collection sites. At a sampling site, one person is designated as "dirty hands" and the other person who is sampling is designated as "clean hands." The dirty hands person is responsible for all activities that do not involve direct handling of the sample and its container, such as handling all other potentially contaminated equipment, clothing, etc. The clean hands sampler is involved in direct handling of the sample container and transfer of the sample from the collection device to the sample container. Water samples should be collected in ultra clean 250-mL FLPE bottles. A Hg laboratory with experience in low level $\mathrm{Hg}$ analysis, such as the USGS Mercury Research Laboratory or Brooks Rand LLC, should provide sample bottles. Grab samples should normally be taken near the centroid of flow, but during high flow, grab samples may occasionally be taken from the streambank. Care should be taken not to disturb bed sediments before sample collection. For TotHg, the sample container should be filled partially and emptied 3 times prior to its final filling. The sample container should then be rapidly submersed, filled, and capped while submersed so that there is no headspace of air. Water samples for $\mathrm{Hg}$ and $\mathrm{MMeHg}$ analysis should be preserved with $2 \mathrm{~mL}$ of Ultrex $6 \mathrm{~N} \mathrm{HCl}$ (Olson and DeWild, 1999).
For collection of filtered water for TotHg and MMeHg analysis, water should be filtered in the field during collection through an in-line $0.45-\mu \mathrm{m}$ filter pack assembly using a peristaltic pump with Teflon ${ }^{\circledR}$ tubing. Water samples should be acidified with ultra-pure $6 \mathrm{~N} \mathrm{HCl}$ in the field immediately after collection (Olson and DeWild, 1999). Samples should be kept on ice until shipped. Water samples should be shipped on wet ice to arrive the next morning at the analytical facilities at temperatures ranging from 1 to $4^{\circ} \mathrm{C}$; the temperature specified by EPA Method 1631E to minimize biologically induced phase changes and MMeHg degradation.

Water-quality parameters, including $\mathrm{pH}$, conductivity, dissolved oxygen, oxidation-reduction potential (ORP), and temperature should be measured in the field with a multi-probe metering device (for example, Hydrolab ${ }^{\mathrm{TM}}$ or $\mathrm{YSI}^{\mathrm{TM}}$ ), either by placing the probe directly into the flowing stream water, or by filling a container and placing it over the probe. If a multi-probe metering device is not available, the following meters are recommended. Values of $\mathrm{pH}$ should be determined using an Orion 250A or 290A meter with a gel-filled Triode electrode, or comparable $\mathrm{pH}$ meter. The $\mathrm{pH}$ meter should be calibrated using commercially available $\mathrm{pH} 10$ and 7 buffers. Water temperatures should be measured using a thermometer that was checked against a thermometer certified by the American Society for Testing and Materials (ASTM). Specific conductance should be determined using a Cole-Parmer meter and probe; a one-point calibration should be done with a standard in the approximate concentration range of the unknown water. Dissolved oxygen should be determined using a YSI meter and probe, calibrated using standard procedures.

\section{High-Flow Event Sampling}

The high flow sampling should be carried out using the same protocol used for the seasonal sampling of water under low flow conditions. The high flow sampling should be carried out by starting at the upper part of the watershed and continuing to the lowest sample site in the watershed. It is important to collect the sample in the centroid of the stream, if possible. In order to assess $\mathrm{Hg}$ release from the Rathburn and Petray mines, Tributary 1 (fig. 4) should be sampled just above its intersection with the Bear Fault. Water samples should be collected for analysis of $\mathrm{Hg}$ and $\mathrm{MMeHg}$ on unfiltered and filtered fraction. It is not necessary to collect a sediment sample. Automated samplers should be considered for use because staff may not always be available for a highflow event. The automated ISCO samplers with Teflon ${ }^{\circledR}$ tubing are suggested for use to collect stream water samples. Control studies using ISCO samplers have documented only minimal contamination of sample bottles from dry deposition of airborne $\mathrm{Hg}$, and reliable results are obtained when $\mathrm{Hg}$ concentrations are greater than 5 pptr (Riscassi and others, 2008). 


\section{Sediment Collection and Analysis}

Sediment samples collected using polycarbonate or Teflon ${ }^{\circledR}$ spoons should be transferred to Teflon ${ }^{\circledR}$ or acidwashed glass containers, following the protocols described by Shelton and Capel (1994). Representative sediment should be collected from in-stream sites, avoiding large pebbles, twigs, and roots. Excess water should be decanted from the container. Sediment samples collected for analysis of TotHg and MMeHg are frozen with dry ice immediately after collection, kept frozen, and shipped on dry ice so that they are received frozen at the analytical facility, and kept frozen there until analysis is initiated. Sediment should be analyzed for TotHg and MMeHg, and percent solids should be determined for reporting results on a dry weight basis. Analysis of TotHg should be carried out according to USEPA method 1631 and for MMeHg according to USEPA method 1630.

\section{Biological Matrices}

This protocol documents procedures for collecting and processing aquatic invertebrates and fish for estimation of Hg bioaccumulation in biota of the Bear Creek watershed. Concurrent sampling for $\mathrm{Hg}$ and $\mathrm{MMeHg}$ in water and sediments will provide information regarding sources and relative bioavailability of $\mathrm{Hg}$ at each site (see above).

Clean techniques are essential to minimize potential contamination, including contact with personnel and equipment. The field methods described here are based on guidelines developed in conjunction with the National WaterQuality Assessment (NAWQA) Program, the Toxic Substances Hydrology Programs, and researchers from other disciplines in the USGS as described by Scudder and others (2008).

This protocol will focus on smaller individuals of upper trophic level predatory fish whenever possible. Smaller fish provide a more short-term representation of changes in $\mathrm{Hg}$ concentrations of prey species, which in turn will reflect short-term changes in Hg in water and sediments. Fish of lower trophic levels also will be collected, especially where predominantly piscivorous species are not available. TotHg and $\mathrm{MMeHg}$ will be analyzed in individual samples of fish during the first year of the study to confirm the percentage of TotHg as MMeHg. If, as predicted, the percentage of TotHg that is MMeHg is high (>95 percent) in the sampled fish, then it will be sufficient in subsequent years to analyze the fish samples only for TotHg. Once the percentage of TotHg as MMeHg is established for those species, only TotHg need to be analyzed. Previous studies have shown that about 95 percent of TotHg in fish muscle tissue is MMeHg (Huckabee and others, 1979; Bloom, 1992; Wiener and Spry, 1996).

Skin-off fillets of top-level piscivores will be analyzed as well as individual whole bodies (less gut contents) of the lower trophic level fish. In addition, because the cost for $\mathrm{MMeHg}$ analyses greatly exceeds that for TotHg, the elimination of the redundant $\mathrm{MMeHg}$ analyses will provide significant cost savings yet will not compromise the validity of the data. Whole-body aquatic invertebrates, however, should be analyzed for both TotHg and MMeHg every year, because the ratios of MMeHg to TotHg tend to be inconsistent among invertebrate taxa, among sites and among years (Mason and others, 2000; Haines and others, 2003; Wiener and others, 2007).

Biological samples, as well as water and sediment samples, need to be collected concurrently or within a short time period ( 2 weeks for invertebrates and forage fish; 4 weeks for top predator fish) to minimize changes that might affect relative $\mathrm{Hg}$ concentrations in the various media collected. In addition, sample collection of each media type must be coordinated to minimize risk of site disturbance and sample contamination. For example, collection of biota at a given site before water and sediment will likely stir up bottom sediment producing conditions unsuitable for water and sediment sampling. At each site, a typical order for sample collection would be water, followed by sediment, then invertebrates, and finally fish. Protocols for sample collection, processing, labeling, submission, and for data management should be reviewed by all field personnel prior to sample collection. See Scudder and others (2008) for examples.

Sampling sites for the Bear Creek watershed (table 1, fig. 1) were selected based on spatial relationships (both above and below) to known natural and anthropogenic sources of $\mathrm{Hg}$ within the watershed and potential for bioaccumulation by biota. In addition, data from previous biological studies (Schwarzbach and others, 2001; Slotton and others, 2004; Hothem and others, in press) were used to assess the most useful sites for a comprehensive, but cost-effective, evaluation of $\mathrm{Hg}$ bioaccumulation before and after restoration.

\section{Invertebrates}

The target macroinvertebrates for this study (Merritt and Cummins, 1995) should be predatory or filter-feeding insects, depending on their abundance and availability at sampling sites. Aquatic invertebrates can serve as excellent bioindicators of metals contamination (Cain and others, 1992). At least three key invertebrate taxa should be targeted for sampling (table 2). As feasible, these taxa should represent different functional feeding categories (for example, scrapers, shredders, grazers, collectors/gatherers) and should be taxa and sizes that are considered important prey items for target fish. For the lotic habitats (streams and flowing channels) of the Bear Creek watershed, preferred macroinvertebrates should be larval caddisflies (Trichoptera, family Hydropsychidae), larval dragonflies (Odonata, Anisoptera, family Gomphidae, Aeshnidae, and Libellulidae), and adult water striders (Hemiptera, family Gerridae). Invertebrates should be sorted to the lowest practical taxon, normally family, and processed as single-taxon composites. For example, one or more species of net-spinning caddisfly larvae in the family Hydropsychidae could form a composite sample. If available, water striders might represent a good sentinel species because they have been found to quantify accurately the food chain entry of $\mathrm{Hg}$ 
Table 2. Available and Target* invertebrate families, Bear Creek.

\begin{tabular}{|c|c|c|c|c|}
\hline Order & Common name & Family name & Trophic level & Previously sampled \\
\hline \multirow[t]{2}{*}{ Hemiptera } & Water strider adult* & Gerridae & Large predator & No \\
\hline & Creeping water bug adult & Naucoridae & Large predator & Slotton and others 1997, 2004 \\
\hline \multirow[t]{5}{*}{ Odonata } & Dragonfly larvae* & Gomphidae & Large predator & $\begin{array}{l}\text { Schwarzbach and others 2001; Slotton and } \\
\text { others } 2004\end{array}$ \\
\hline & Dragonfly larvae* & Aeshnidae & Large predator & No \\
\hline & Dragonfly larvae* & Libellulidae & Large predator & $\begin{array}{l}\text { Slotton and others 1997, 2004; Schwarzbach } \\
\text { and others } 2001\end{array}$ \\
\hline & Damselfly larvae & Calopterygidae & Small predator & $\begin{array}{l}\text { Slotton and others 1997; Schwarzbach and } \\
\text { others } 2001\end{array}$ \\
\hline & Damselfly larvae* & Coenagrionidae & Small predator & Slotton and others 2004 \\
\hline Trichoptera & Net-spinning caddisfly larvae* & Hydropsychidae & Drift feeder & $\begin{array}{l}\text { Slotton and others 1997, 2004; Schwarzbach } \\
\text { and others } 2001\end{array}$ \\
\hline \multirow[t]{2}{*}{ Ephemeroptera } & Mayfly larvae & Ephemerellidae & Herbivore & Slotton and others 1997, 2004 \\
\hline & Mayfly larvae & Siphlonuridae & Herbivore & Slotton and others 1997 \\
\hline \multirow[t]{2}{*}{ Diptera } & Cranefly larvae & Tipulidae & Large predator & Slotton and others 1997, 2004 \\
\hline & Soldier fly larvae & Stratiomyidae & Small predator & Slotton and others 2004 \\
\hline Plecoptera & Golden stonefly larvae & Perlidae & Small predator & Slotton and others 1997 \\
\hline \multirow[t]{2}{*}{ Megaloptera } & Alderfly larvae & Sialidae & Small predator & Slotton and others 1997 \\
\hline & Dobsonfly larvae & Corydalidae & Large predator & Slotton and others 1997, 2004 \\
\hline Coleoptera & Riffle beetle adult & Elmidae & Large predator & Slotton and others 2004 \\
\hline
\end{tabular}

(Jardine and others, 2005). However, because of the high variability of $\mathrm{Hg}$ in water striders from aquatic systems, especially among different seasons, care should be taken to understand the potential short-term variations in Hg sources to the streams being sampled (see Jardine and others 2009). For all sites, alternate species of invertebrates should be identified and collected the first year to serve as functionally equivalent substitutes in case adequate numbers of primary target species are not available. Some invertebrates may be unsuitable because of their small size (for example, Chironomidae), because expending the time needed to collect sufficient mass for chemical analyses may not be feasible.

Fish

Black basses (Centrarchidae: Micropterus spp.) are excellent target species (May and others, 2000), but previous studies have not been successful at collecting black bass from Bear Creek sites. Predatory fish can serve as good bioindicators of metals contamination in the long term (Wiener and Spry, 1996), but considering the ephemeral nature of the streams in parts of the Bear Creek watershed, other fish should be collected wherever possible. One or two other species will need to be identified that can be collected across all study sites. Species that have been collected in previous studies (Slotton and others, 1997, 2004; Schwarzbach and others, 2001) include Sacramento pikeminnow, Sacramento sucker, and California roach. The species of fish that is most likely to be collected is the California roach. The collection of the same species at each site allows for comparison among sites across geographical areas. The use of target taxa allows for comparison among sites across geographical areas. Alternate species will be identified for each site. Two species of forage fish and one species of top predator fish (table 3) will be collected, as available, at each site; these will be identified in the field to the lowest possible taxonomic category and processed individually. Alternate species of acceptable forage fish and top predator fish also will be identified for all sites to serve as functionally equivalent substitutes in the case that adequate numbers of primary target species are not collected.

Preference should be given to fish that are resident (for example, speckled dace), avoiding whenever possible sampling areas where fish are likely to move in and out of other major water bodies. Although speckled dace represent a good potential target species because they have relatively limited movements, short lifespan, and are benthically dependent foragers (for example, on insects), they have not been documented during previous collections and may not be available. Collections during the first year will determine the size ranges available for various fish species and provide guidance for future collections. Depending on the fish species, all individuals used in composite samples should be as similar in size as possible. If large variation in fish size affects the variation in Hg concentrations, then size should be used as a covariate during statistical analysis to control for this effect while comparing differences in Hg concentrations among sites. 
Table 3. Available and Target* fish species, Bear Creek.

\begin{tabular}{llll}
\hline \multicolumn{1}{c}{ Family name } & \multicolumn{1}{c}{ Common name } & \multicolumn{1}{c}{ Scientific name } & \multicolumn{1}{c}{ Previously sampled } \\
\hline Centrarchidae & Smallmouth bass & Micropterus dolomieui & No \\
& Bluegill & Lepomis macrochirus & No \\
& Green sunfish & Lepomis cyanellus & Slotton and others 2004 \\
Cyprinidae & Sacramento pikeminnow* & Ptychocheilus grandis & Slotton and others 2004; Schwarzbach and others 2001 \\
& California roach* & Hesperoleucus symmetricus & Slotton and others 2004; Schwarzbach and others 2001 \\
Catastomidae & Speckled dace* & Rhinichthys osculus & No \\
& Sacramento sucker* & Catostomus occidentalis & Slotton and others 2004; Schwarzbach and others 2001 \\
\hline
\end{tabular}

Table 4. Summary of invertebrate and fish sample collections for Bear Creek Watershed.

\begin{tabular}{|c|c|c|c|c|c|c|c|c|c|c|c|c|}
\hline \multirow{3}{*}{ Collection Season } & \multicolumn{6}{|c|}{ Pre Cleanup } & \multicolumn{6}{|c|}{ Post Cleanup } \\
\hline & \multicolumn{3}{|c|}{ Year 1} & \multicolumn{3}{|c|}{ Years 2-5 } & \multicolumn{3}{|c|}{ Year 1} & \multicolumn{3}{|c|}{ Years 2-5 } \\
\hline & Fish & & Inverts & Fish & & Inverts & Fish & & Inverts & Fish & & Inverts \\
\hline Spring (April -May) & 3 species & 3 & taxa & & & & 2 species & 2 & taxa & & & \\
\hline Fall (Sept. - Oct.) & 3 species & 3 & taxa & 3 species & 3 & taxa & 2 species & 2 & taxa & 3 species & 3 & taxa \\
\hline
\end{tabular}

\section{Preparation for Collections}

Suggested equipment and supplies for use in these biological studies are listed in tables 5 and $\underline{6}$. Equipment and supplies need to be properly prepared to minimize the potential for sample contamination. New, sealed supplies such as zip-seal plastic bags and plastic vials with plastic caps do not need pre-cleaning. However, reusable equipment will need to be cleaned properly prior to field collections (see Scudder and others, 2008, for techniques). After tools are cleaned, supplies and smaller equipment will be double-bagged in new plastic bags and stored in sealed containers to minimize contamination; supplies should be cleaned and packed separately for each site to minimize the need for field cleaning (Brumbaugh and others, 2001). In the field, all equipment should be cleaned between sites.

Field forms (appendixes A and B), sample labels (appendix C), and laboratory submission forms (appendix D) should be prepared prior to collecting samples and should be printed on durable water-proof paper (for example, Rite-InThe-Rain ${ }^{\mathrm{TM}}$ paper). Field forms and labels should be preprinted with station name, analyte, medium code, and contact information (name and telephone number). For other examples of such forms, see Scudder and others (2008).

California scientific collection permits, obtained from the California Department of Fish and Game, will be required for collections of invertebrates and fish. Landowner permissions will be required for access to sites located on private property or when site access requires crossing private property.
A consultation with local U.S. Fish and Wildlife Service personnel with regard to Section 7 of the Endangered Species Act is recommended and may be required in some locations if a threatened or endangered species is known or thought to be present (http://www.fws.gov/endangered/factsheets/ consultations.pdf).

\section{Quality Assurance and Quality Control (OA/OC)}

Quality-assurance samples are collected to investigate field and laboratory variability. Triplicate invertebrate composite samples (three individuals per species) and multiple individual fish samples in this protocol serve as qualityassurance replicates for field variability. Quality assurance for laboratory analyses will include duplicate runs, blanks, spikes, and use of certified or standard reference sample materials. Voucher specimens for taxonomic confirmation should be preserved in 70-percent ethanol (invertebrates). Techniques used for biota must ensure that tissues are not contaminated during collection or during sample processing. Processing on site or at a nearby outdoor area is acceptable if a stable, clean work area is available. However, processing in an enclosed facility, such as a field laboratory, is preferred. Disposable, powder-free latex gloves must be worn during all sample processing and must be changed frequently, particularly after touching any unclean surface. 
Table 5. Equipment checklist (modified from Scudder and others 2008).

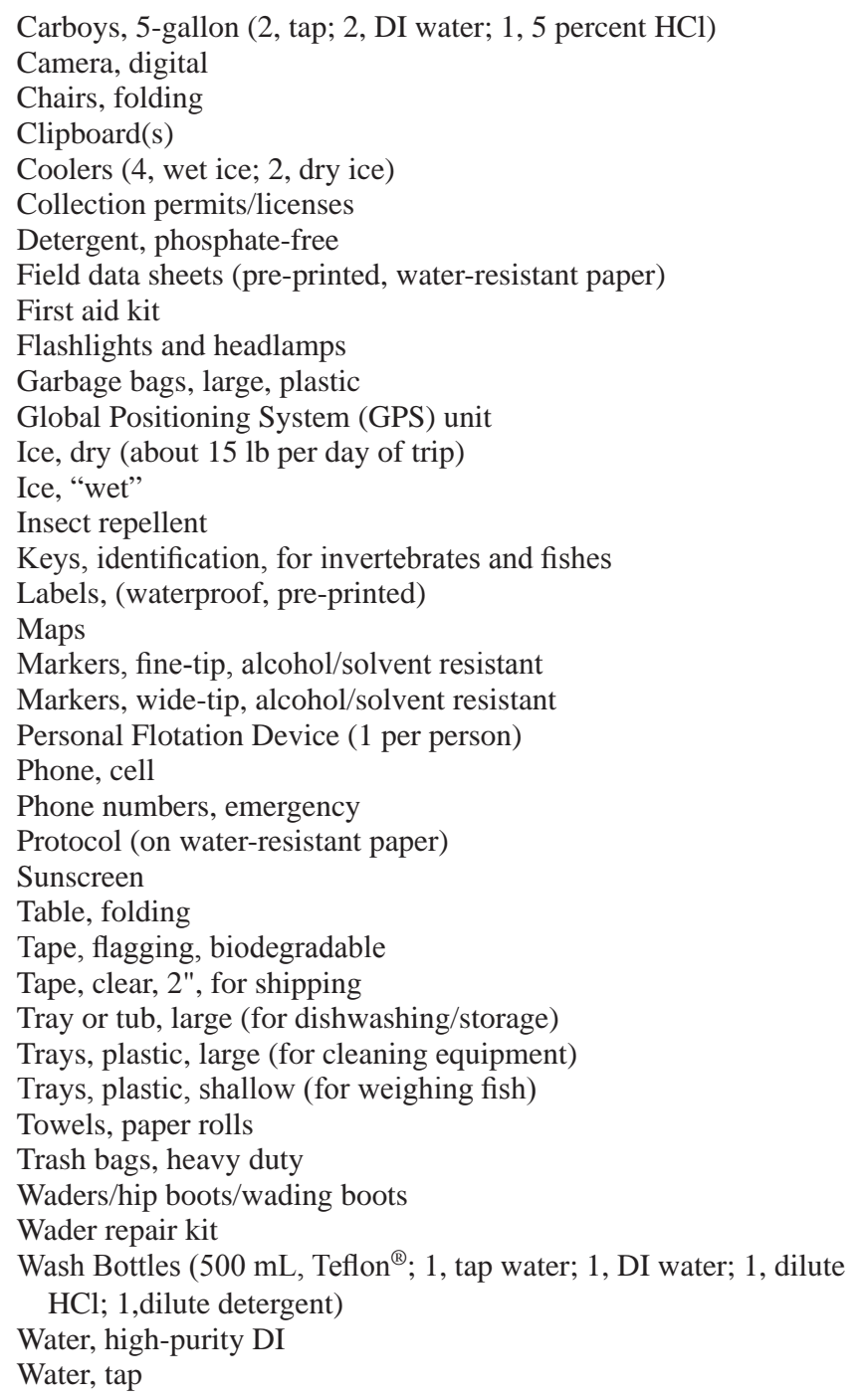

\section{Sample Collection and Processing}

A summary of invertebrate and fish sample-collection plans is provided in table 4. Additional taxa may be collected as available.

\section{Invertebrates}

Invertebrate sampling should be conducted in spring (April-May) and late summer/fall (August-September) in the first year of the study (Pre-R) and the first year after restoration (Post-R) to evaluate inter-seasonal differences in $\mathrm{Hg}$ bioaccumulation. Invertebrates may be collected using dip nets, kick nets, or by hand and placed into labeled plastic bags or containers. At least $1 \mathrm{~g}$ wet weight of each taxon will be required to ensure sufficient biomass for analyses (minimum
Table 6. Fish and invertebrate collection checklist (modified from Scudder and others, 2008).

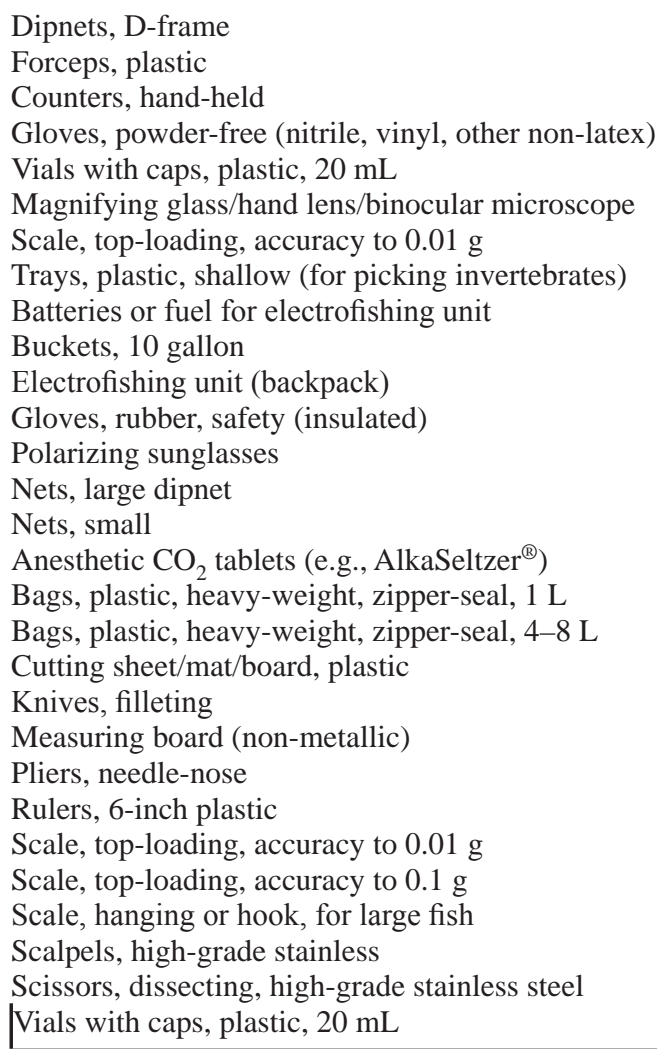

of $0.1 \mathrm{~g}$ dry weight) (Hall and others, 1998). Depending on the size of the invertebrates collected, the number of individuals needed to obtain $1 \mathrm{~g}$ wet weight will vary but, in any case, will likely not be less than three individuals. Small invertebrates, such as caddisfly larvae, may require up to 150 individuals. Collectors should attempt to be consistent with selection of species and size classes within a species and should collect each taxon from as broad a range of locations within a reach as possible. Because the number of individuals comprising each sample will drive $\mathrm{Hg}$ concentration variability, that number should be held constant for each species being sampled. This will be determined most easily after the first Pre-Remediation sampling and attempts should be made to maintain this number of individuals throughout the study period.

Invertebrates should be processed as three replicate composite samples for each taxon with the same number of organisms, of similar size, in each composite sample. Holding (depuration) times should typically range from a few to 24 hours per site, depending on the time of day collected. Voucher specimens of each uncertain taxon should be collected for taxonomic confirmation. Within 24 hours, individuals should be sorted by family and placed in disposable dishes using Teflon ${ }^{\circledR}$-coated forceps or gloved-hand. Organisms are to be 
rinsed clean with DI water and patted dry with a clean paper towel. Composite samples, consisting of 3-150 individuals of the same family (1-5 g, wet weight), should then be weighed and placed into chemically cleaned glass jars with Teflon ${ }^{\circledR}$ lined lids. Processed samples should then be preserved immediately on dry ice for transport to a freezer where they should be kept frozen for no more than 6 months until they can be shipped to an approved analytical laboratory. Each composite sample of invertebrates should be analyzed for TotHg and MMeHg. If sample mass is insufficient for both analyses, the priority analysis is MMeHg.

\section{Fish}

A variety of fish-collection procedures may be appropriate, depending on site conditions and target species. General fish-collection procedures are described elsewhere (Meador and others, 1993; Moulton and others, 2002), and rely primarily on backpack electrofishing. Other methods in combination with or in lieu of electrofishing, such as seining or rod-and-reel (with artificial lures), or passive gear, such as traps or nets, may be more effective at some sites and would be acceptable. After capture, fish should be placed in a large plastic bucket in native water until they can be processed. Guidelines for live specimen handling and care are provided in Walsh and Meador (1998). Fish can be anesthetized using carbon dioxide from carbon dioxide-producing tablets, such as Alka-Seltzer ${ }^{\circledR}$ (2-4 tablets per gallon of water in bucket or other container). After anesthetization, fish can be euthanized by additional carbon dioxide (recommended by Walsh and Meador, 1998). Fish that are to be processed in a location other than the collection site should be placed in clean zip-seal bags on wet ice and processed within 24 hours. If they cannot be processed within 24 hours, they should be placed in a cooler on dry ice and kept frozen until they can be processed.

Fish should be collected both in spring and fall in the first Pre-R year of the study and in the first Post-R year of the study. Fish should be collected from the same sites as the water, invertebrates, and sediments and at each site, a typical order for sample collection would be water, followed by sediment, then invertebrates, and finally fish. Three species of fish, depending on availability, should be collected from each sample site. Initially, at each site, the goal is to collect five individuals of each species of similar size/length. Fish should be analyzed for MMeHg and TotHg during year 1 of Pre-R sampling and TotHg only during subsequent years. Detailed procedures for processing fish are provided by Scudder and others (2008). Upper trophic level fish are longer lived with slower tissue turnover than forage fish, so they do not have to be collected at exactly the same time as the rest of the biota. At each site, five similar-sized mature individuals of the target top predator fish should be collected. This size should be maintained throughout the entire study. A second species of piscivorous fish may be sampled if availability of the primary target species is limited.

As indicated earlier, additional species of fish should be collected wherever possible. The preferred fish that may be collected is the California roach. Captured fish should be held in native water in buckets until they are weighed and measured for standard and total length. Each individual fish should then be labeled, placed in a polyethylene zip-lock bag and placed on dry ice in a cooler. Samples should be stored frozen until they can be processed further. Each fish should be measured for standard and total length $( \pm 0.5 \mathrm{~mm})$ and the total mass determined ( $\pm 0.5 \mathrm{~g}$ ) on an electronic balance. In the laboratory, fillet tissue from top-level predatory fish should be dissected following procedures described by May and others (2000). The whole bodies of small fish should be analyzed, after removing the contents of the gastrointestinal tract. Tissues to be analyzed should be placed in chemically clean glass sample jars with Teflon ${ }^{\circledR}$-lined lids. Processed samples should be preserved immediately on dry ice for transport to a freezer or analytical laboratory and analyzed as soon as possible, preferably within 6 months.

\section{Sample Shipment}

Before they are shipped to the contract laboratory for analysis, all sample data must be entered on the appropriate sample chain-of-custody forms (included in the packaging), and the analytical laboratory must be notified to ensure that they can receive the samples. Ship frozen samples for next-day delivery (for example, FedEx ${ }^{\circledR}$ ); ensuring that sufficient dry ice is included in the packaging so that a 1-day delay will not adversely affect the samples. Samples should be shipped on Mondays or Tuesdays to minimize the likelihood of a shipping error causing samples to sit over a weekend.

\section{Statistics}

TotHg and MMeHg concentrations in all matrices (water, sediments, invertebrates, fish) should be compared statistically among sites and sampling periods. However, limited availability of certain invertebrate and fish taxa at some sites and limited replication may restrict the statistical power (probability) for detecting certain effects, in which case only qualitative inter-site comparisons may be useful. Using the scientific literature, potential impacts of the observed $\mathrm{Hg}$ concentrations on the reproduction, growth, metamorphosis, and survival of each taxon should also be evaluated for the species sampled as well as other species present in the watershed.

To avoid biasing the results of the data analysis towards spurious patterns in the data, any hypotheses intended for statistical evaluation should be developed a priori. For 
example, if a simple assessment of change is desired, the following hypotheses can be developed a priori:

$\mathrm{H}_{\mathrm{o}}=\mathrm{Hg}$ concentrations for [matrix] during Post-R year(s) are statistically indistinguishable from $\mathrm{Hg}$ concentrations during Pre-R year(s).

$\mathrm{H}_{1}=\mathrm{Hg}$ concentrations for [matrix] during Post-R year(s) are statistically different from $\mathrm{Hg}$ concentrations during Pre-R year(s).

If desired, these hypotheses can be generalized to include trends characterized by relatively sustained rates of continuous change. For example, if an analysis of change in Post-R years is desired, then a linear regression model could be applied and the following hypotheses developed:

$\mathrm{H}_{\mathrm{o}}=$ The slope of Hg concentrations for [matrix] over time during Post-R year(s) is statistically indistinguishable from zero (that is, no change).

$\mathrm{H}_{1}=$ The slope of $\mathrm{Hg}$ concentrations for [matrix] over time during Post-R year(s) is statistically different than zero (that is, indicating an increase or decrease in $\mathrm{Hg}$ concentration).

These hypotheses can be evaluated with a wide variety of models ranging from simple (that is, two-sample t-test and simple linear regression) to complex models depending on additional sampling factors that could influence and/or confound with the variation in Hg concentrations (such as site, year, flow events, and fish size). However, complex models require larger sample sizes in order to reliably identify and account for the effects associated with these additional factors. Therefore, even if additional factors were to confound with the difference between Pre-R and Post-R periods, small sample sizes could reduce the ability to account for them and this would diminish the interpretability of the comparisons.

Because the extent to which variation in the data exists cannot be determined a priori, then the specific appropriate statistical model might best be chosen after patterns in the initial data are evaluated. At a minimum, a one-factor ANOVA model comparing Pre-R and Post-R, essentially equivalent to a two-sample t-test, can evaluate the first hypothesis. Ideally, a Repeated Measures ANOVA model (for example, based on a linear mixed effects model structure) should be considered, using data from multiple sites as the repeated measures sampling units at each time interval. Covariates such as site, timing, water flow, and fish size should be added to this type of model as appropriate. With sufficiently abundant data, multiple comparisons tests (for example, Student-NewmanKeuls or Tukey's Multiple Comparisons Tests) can be used to compare Pre-R data from 1 or 2 years versus multiple years of Post-R data. This would allow statistical comparisons between and among individual year pairs as well as groupings of years. However, if data are limited, this approach would have less statistical power than using simpler and more direct statistical approaches.
Because inter-annual variability, especially with respect to the frequency and intensity of rainfall events (and possibly the flow rates of Hg-laden cold or hot springs), may result in significant variations in the $\mathrm{Hg}$ concentrations observed in water, sediments, and biota, it is important to assess multiple years for both the Pre-R Phase and Post-R Phase. In order to account for inter-annual variability in rainfall and natural spring activity, it is recommended that 5 years of Pre-R and 5-10 years of Post-R sampling should be conducted, with preference for more years when possible.

\section{Power and Sample Size for Testing Percent Difference Between Pre-R and Post-R Periods}

Because the statistical power to detect changes in Hg concentrations for all matrices would be enhanced by increasing sample sizes, to offset the uncertainty associated with sampling variation, a formula for determining adequate sample size to detect specific levels of change is provided below. This formula only applies to situations where the twosample t-test will be used. A comparable formula for repeated measures ANOVA would require more variables and is difficult to express without yet having a detailed specification for that model. Therefore, this formula is intended only to provide a starting point for determining the adequacy of the protocol sample size after initial data has been gathered.

The minimum sample size for detecting an effect is determined by sampling variation (to be determined from initial data), the anticipated size of the effect, and the desired power for detecting that effect. A percent change in Hg between two periods can be expressed as an absolute difference in log-transformed Hg. For example, a hypothetical change of $\mathrm{D}$ percent (for example, $\mathrm{D}=-15$ would be a 15 percent decrease) in Hg concentrations from Pre-R to Post-R treatment periods is equivalent to having the ratio of Hg from Post-R to Pre-R treatment periods $=1+(\mathrm{D} / 100)$ (for example, 0.85). Equivalently, this ratio can be expressed in terms of the difference $\delta=\ln ($ Post $)-\ln ($ Pre $)=\ln ($ Post $/$ Pre $)$ $=\ln (1+(\mathrm{D} / 100))$, where $\ln ($ Post $)$ and $\ln ($ Pre $)$ correspond to average natural log transformed $\mathrm{Hg}$ levels from Post-R and Pre-R periods respectively. The minimum sample size (n) required for a minimum prescribed power (1- $\beta$ ) of detecting a $\mathrm{D}$ percent change sample when testing at the a significance level should satisfy the following inequality (Zar, 1999, section 8.4):

$$
n \geq \frac{2 s^{2}}{\delta^{2}}\left(t_{\alpha(1), v}+t_{\beta(1), v}\right)^{2}
$$

where $s^{2}=$ within-period variance among samples (withinPre-R and within-Post-R sampling variance are assumed to be equal), $v=2(n-1)$, and $t_{\alpha(1), v}$ and $t_{\beta(1), v}$ are 1-sided critical values of the $t$-distribution with $v$ degrees of freedom and $\alpha$ and $\beta$ tail probabilities respectively (Zar, 1999, table B.3 in appendix B). 
This formula can be rearranged algebraically to determine, for a given sample size, the power of detecting an effect, $1-\beta$, where $\beta$ satisfies the following inequality:

$$
t_{\beta(1), v} \leq \frac{\delta}{\sqrt{2 s^{2} / n}}-t_{\alpha(1), v} .
$$

Power, significance level, and sample size are interrelated such that by enhancing any one of the three, then one or both of the other two will be compromised. For example, an effect detected at the $\alpha=0.10$ significance level would provide a reasonable confidence that a change occurred (as opposed to being a spurious statistical pattern). Comparatively, an effect detected at the $\alpha=0.05$ significance level would provide even greater confidence that a change had occurred, but there will be either a reduced power of making that detection, or an increased sample size will be required to maintain the same power as for detecting effects at the $\alpha=0.10$ significance level.

\section{Analytical Costs}

The estimated prices for chemical analyses of water, sediment, and biota are listed in table 7. The prices are based on a minimal sampling protocol, with 1 year of Pre-R and 5 years of Post-R sampling. These prices do not include any potential volume discounts or other discounts that individual laboratories might offer. The cost of sampling at each site is based on analysis of TotHg and $\mathrm{MMeHg}$ on an unfiltered and filtered water sample and a sediment sample. The percent solids also will be determined for the sediment sample so that results can be reported on a dry weight basis. The highflow sampling event includes analysis of TotHg and $\mathrm{MMeHg}$ analysis on an unfiltered and filtered water sample at each site but no collection of a sediment sample. A summary of costs for water and sediment per site is presented in table 8 .

The estimated costs for chemical analyses of biotic samples are shown in table 7. These prices do not include any
Table 7. Estimated costs of individual analyses. ${ }^{1}$

\begin{tabular}{llc}
\hline & Unit & Unit Price \\
\hline Water samples for total Hg analyses & EA & $\$ 80$ \\
Water samples for MMeHg analyses & EA & $\$ 160$ \\
Sediment samples for total Hg analyses & EA & $\$ 110$ \\
Sediment samples for MMeHg analyses & EA & $\$ 210$ \\
Sediment percent solids for result on dry & EA & $\$ 10$ \\
$\quad$ weight basis & & \\
Biological samples for total Hg analyses & EA & $\$ 110$ \\
Biological samples for MMeHg analyses & EA & $\$ 160$ \\
Determination of tissue percent solids & EA & $\$ 10$ \\
Sample homogenization & EA & $\$ 20$ \\
Total cost for total Hg only & & $\$ 140$ \\
Total cost for total and MMeHg & & $\$ 300$ \\
\hline
\end{tabular}

${ }^{1}$ Based on November 2008 cost estimate from Brooks Rand Laboratories, Seattle, WA.

potential volume or other discounts that individual laboratories might offer. The proposed numbers of samples of fish and invertebrates by year for 10 sites and the estimated costs per year are shown in table 9 . The total numbers of samples collected in the first year are not all proposed for analysis (table 2). Instead, those collections are intended to determine the taxa available at each site. The taxa that are most common at the most sites are those that should be proposed for analyses in the first and subsequent years. Seasonal availability will be a factor to consider the first year as well. As discussed above, sampling during subsequent years should be performed during the season that is determined to be optimal for evaluation of $\mathrm{Hg}$ bioaccumulation in the Bear Creek watershed, likely the season with the highest production of MMeHg.

The total costs, with the assumptions listed in the footnotes, are presented in table 10 . No cost of living or inflationary factors were included in the cost estimates. In addition, costs will vary depending on the availability of “in-kind” services, available equipment and supplies, and travel costs.

Table 8. Summary of water and sediment chemical analyses per site for Bear Creek watershed.

\begin{tabular}{|c|c|c|c|c|c|c|c|c|}
\hline \multirow{2}{*}{ Collection Season } & \multicolumn{4}{|c|}{ Pre Cleanup } & \multicolumn{4}{|c|}{ Post Cleanup } \\
\hline & Water $^{1}$ & Sediment $^{2}$ & Water ${ }^{1}$ & Sediment $^{2}$ & Water $^{1}$ & Sediment $^{2}$ & Water $^{1}$ & Sediment $^{2}$ \\
\hline Spring (April -May) & $\$ 530$ & $\$ 330$ & & & $\$ 530$ & $\$ 330$ & & \\
\hline Fall (Sept. - Oct.) & $\$ 530$ & $\$ 330$ & $\$ 530$ & $\$ 330$ & $\$ 530$ & $\$ 330$ & $\$ 530$ & $\$ 330$ \\
\hline Cost per site per year & $\$ 1,060$ & $\$ 660$ & $\$ 530$ & $\$ 330$ & $\$ 1,060$ & $\$ 660$ & $\$ 530$ & $\$ 330$ \\
\hline Total cost per year & \multicolumn{2}{|c|}{$\$ 22,500$} & \multicolumn{2}{|c|}{$\$ 13,900$} & \multicolumn{2}{|c|}{$\$ 22,500$} & \multicolumn{2}{|c|}{$\$ 13,900$} \\
\hline Cost per period & \multirow{2}{*}{\multicolumn{2}{|c|}{$\$ 22,500$}} & \multirow{2}{*}{\multicolumn{2}{|c|}{$\$ 55,600$}} & \multirow{2}{*}{\multicolumn{2}{|c|}{$\$ 22,500$}} & \multicolumn{2}{|c|}{$\$ 55,600$} \\
\hline 10 -year total & & & & & & & $\$ 15$ & 200 \\
\hline
\end{tabular}

\footnotetext{
${ }^{1}$ Based on one water sample per site per collection season for filtered and unfiltered $\mathrm{Hg}$, and filtered and unfiltered $\mathrm{MMeHg}$.

${ }^{2}$ Based on one sediment sample per site for $\mathrm{Hg}, \mathrm{MMeHg}$, and determination of percent solids for reporting concentration on a dry weight basis.
} 
Table 9. Summary of invertebrate and fish chemical analyses per site for Bear Creek watershed.

\begin{tabular}{|c|c|c|c|c|c|c|c|c|}
\hline \multirow{3}{*}{ Collection Season } & \multicolumn{4}{|c|}{ Pre Cleanup } & \multicolumn{4}{|c|}{ Post Cleanup } \\
\hline & \multicolumn{2}{|c|}{ Year 1} & \multicolumn{2}{|c|}{ Years 2-5 } & \multicolumn{2}{|c|}{ Year 1} & \multicolumn{2}{|c|}{ Years 2-5 } \\
\hline & Fish $^{1}$ & Inverts ${ }^{2}$ & Fish $^{3}$ & Inverts ${ }^{4}$ & Fish $^{3}$ & Inverts 4 & Fish $^{3}$ & Inverts $^{4}$ \\
\hline Spring (April -May) & 15 & 9 & & & 10 & 6 & & \\
\hline Fall (Sept. - Oct.) & 15 & 9 & 10 & 6 & 10 & 6 & 10 & 6 \\
\hline Cost per site per year & $\$ 9,000$ & $\$ 5,400$ & $\$ 1,400$ & $\$ 1,800$ & $\$ 2,800$ & $\$ 3,600$ & $\$ 1,400$ & $\$ 1,800$ \\
\hline Cost per period & \multirow{2}{*}{\multicolumn{2}{|c|}{$\$ 144,000$}} & \multirow{2}{*}{\multicolumn{2}{|c|}{$\$ 128,000$}} & \multirow{2}{*}{\multicolumn{2}{|c|}{$\$ 64,000$}} & \multirow{2}{*}{\multicolumn{2}{|c|}{$\begin{array}{l}\$ 128,000 \\
\$ 464,000\end{array}$}} \\
\hline 10-year total & & & & & & & & \\
\hline
\end{tabular}

\footnotetext{
${ }^{1}$ Based on three species and five individual fish samples per species (whole bodies for forage fish; fillets for larger piscivorous species) per site; analyze for TotHg and MMeHg in years 1 and TotHg in subsequent years.

2 Based on three composite samples of each analyzed taxon per site; all samples analyzed for both TotHg and MMeHg.

${ }^{3}$ Based on two species and five individual fish samples per species (whole bodies for forage fish; fillets for larger piscivorous species) per site; analyze for TotHg only.

${ }^{4}$ Based on two composite samples of each analyzed taxon per site; all samples analyzed for both TotHg and MMeHg.
}

Table 10. Estimated budget (in dollars) for Federal staff to conduct Bear Creek sampling based on 2009 costs.

\begin{tabular}{|c|c|c|c|c|c|}
\hline & $\begin{array}{l}\text { Year } 1 \\
\text { Pre }\end{array}$ & $\begin{array}{l}\text { Year 2-5 Pre } \\
\text { (per yr) }\end{array}$ & $\begin{array}{c}\text { Year } 1 \\
\text { Post }\end{array}$ & $\begin{array}{l}\text { Year 2-5 Post } \\
\text { (per yr) }\end{array}$ & Total \\
\hline \multicolumn{6}{|l|}{ Personnel: } \\
\hline Biologist ${ }^{1}$ & 6,140 & 3,070 & 6,140 & 3,070 & \\
\hline Geologist $^{1}$ & 6,140 & 3,070 & 6,140 & 3,070 & \\
\hline 2 technicians $^{2}$ & 5,590 & 2,795 & 5,590 & 2,795 & \\
\hline Travel & 1,800 & 900 & 1,800 & 900 & \\
\hline Equipment ${ }^{3}$ & 11,000 & 1,000 & 1,000 & 1,000 & \\
\hline Supplies ${ }^{4}$ & 2,000 & 1,000 & 1,000 & 1,000 & \\
\hline Shipping Costs ${ }^{5}$ & 400 & 200 & 400 & 200 & \\
\hline Chemical Analyses: biota & 144,000 & 32,000 & 64,000 & 32,000 & \\
\hline Chemical Analyses: water \& sediments & 22,500 & 13,900 & 22,500 & 13,900 & \\
\hline Per year totals & 199,570 & 57,935 & 108,570 & 57,935 & \\
\hline 10-year totals & 199,570 & 231,740 & 108,570 & 231,740 & $\$ 771,620$ \\
\hline \multicolumn{6}{|c|}{${ }^{1}$ Based on research scientist (GS-12/1) for 4 weeks/year in first years and 2 weeks/year in 2-5 years (not adjusted for COLA } \\
\hline \multicolumn{6}{|c|}{${ }^{2}$ Based on technician (GS-5/1) for 4 weeks/year in first years and 2 weeks/year in 2-5 years (not adjusted for COLA). } \\
\hline \multicolumn{6}{|c|}{${ }^{3}$ Includes one-time purchase of backpack electrofisher: $\$ 10,000$. Delete if one can be borrowed. } \\
\hline \multicolumn{6}{|c|}{${ }^{4}$ Includes chemically cleaned jars, dissecting equipment, nets, waders, etc. } \\
\hline
\end{tabular}




\section{Summary and Conclusions}

This report summarizes the known information on the occurrence and distribution of $\mathrm{Hg}$ in physical/chemical and biological matrices within the Bear Creek watershed. Multiple sources, both natural and anthropogenic, contribute $\mathrm{Hg}$ to Bear Creek and its tributaries. Previous studies of water, sediment, and biota from the Bear Creek watershed have revealed elevated concentrations of $\mathrm{Hg}$ and $\mathrm{MMeHg}$ in certain areas, notably downstream of sources of $\mathrm{Hg}$ that include both abandoned $\mathrm{Hg}$ and Au mines, ore-processing facilities or natural hot and cold springs. Cumulative data for water, invertebrates, and fish matrices show similar patterns of minimum TotHg and MMeHg concentrations at Upper Bear Creek sites, maximum concentrations in the Sulphur Creek area, and intermediate concentrations downstream of the confluence of Sulphur Creek with Bear Creek.

Based on these data, a matrix-specific monitoring protocol was developed to be used for the evaluation of the effectiveness of $\mathrm{Hg}$ remediation activities in the Bear Creek watershed. The monitoring protocol documents procedures for collecting and processing samples of water, sediment, and biota for estimation of TotHg and MMeHg in the Bear Creek watershed. It also details timing of sampling before and after site remediation and techniques for evaluation of the results of chemical analyses and estimated costs for sampling and analyses.

The concurrent sampling of TotHg and MMeHg in biota as well as water and sediment from 10 monitoring sites will provide information on the relative bioavailability of $\mathrm{Hg}$ released from $\mathrm{Hg}$ sources in the watershed and identify environments conducive to $\mathrm{Hg}$ methylation. The sampling sites were selected based on spatial relationships (both above and below) to known natural and anthropogenic sources of $\mathrm{Hg}$ within the watershed and potential for bioaccumulation by biota. In addition, data from previous biological studies were used to assess the most useful sites for a comprehensive, but cost-effective, evaluation of $\mathrm{Hg}$ bioaccumulation before and after restoration.

This protocol is designed to assist landowners, land managers, water-quality regulators, and scientists in determining whether specific restoration/mitigation actions lead to significant progress toward achieving water quality goals to reduce Hg in the Bear Creek watershed.

\section{Acknowledgments}

We thank Drs. Roger Ashley and Collin Eagles-Smith for peer review and significant improvements in this report. Special thanks also go to Francis Evanisko at the BLM California State Office who provided mapping services. Funds for research and preparation for this report have been provided by a grant from the CALFED Watershed Program and administered by the California Department of Water Resources to the Bureau of Land Management, grant agreement number 4600004720. Additional support has come from the Bureau of Land Management, the Colusa County Resource Conservation District, and the U.S. Geological Survey's Western Ecological Research Center.

\section{References Cited}

Babiarz, C.L., Hurley, J.P., Benoit, J.M., Shafer, M.M., Andren, A.W., and Webb, D.A., 1998, Seasonal influences on partitioning and transport of total and methylmercury in rivers from contrasting watersheds: Biogeochemistry, v. 41, p. 237-257.

Babiarz, C.L., Hurley, J.P., Hoffman, S.R., Andren, A.W., Shafer, M.M., and Armstrong, D.E., 2001, Partitioning of total mercury and methylmercury to the colloidal phase in freshwaters: Environmental Science and Technology, v. 35, p. $4773-4782$.

Balogh, S.J., Nollet, Y.H., and Offerman, H.J., 2005, A comparison of total mercury and methylmercury export from various Minnesota watersheds: Science of the Total Environment, v. 340, p. 261-270.

Bloom, N.S., 1992, On the chemical form of mercury in edible fish and marine invertebrate tissue: Canadian Journal of Fisheries and Aquatic Sciences, v. 49, p. 1010-1017.

Bloom, N.S., 1995, Mercury as a case study of ultra-clean sample handling and storage in aquatic trace metal research: Environmental Laboratory, v. 3-4, p. 20-25.

Bloom, N.S., Preus, E., Katon, J., and Hiltner, M., 2003, Selective extractions to assess the biogeochemically relevant fractionation of inorganic mercury in sediments and soils: Analytica Chimica Acta, v. 479, p. 233-248.

Bosworth, D., and Morris, P., 2009, Bear Creek Mercury Inventory: Regional Water Quality Control Board Central Valley Region Staff Report, June 2009, 28 p. Available at: http://www.swrcb.ca.gov/rwqcb5/water_issues/tmdl/ central valley projects/cache sulphur creek/bear ck report jun 09.pdf.

Brumbaugh, W.G., Krabbenhoft, D.P., Helsel, D.R., Wiener, J.G., and Echols, K.R., 2001, A national pilot study of mercury contamination of aquatic ecosystems along multiple gradients: Bioaccumulation in fish: U.S. Geological Survey Biological Science Report USGS/BRD/ BSR-2001-0009, 25 p.

Bureau of Land Management, 2004, Cache Creek Coordinated Resource Management Plan/ Environmental Assessment Final: Ukiah, Calif. Field Office, $120 \mathrm{p}$. 
Cain, D.J., Luoma, S.N., Carter, J.L., and Fend, S.V., 1992, Aquatic insects as bioindicators of trace element contamination in cobble-bottom rivers and streams: Canadian Journal of Fisheries and Aquatic Sciences, v. 10, p. 2141-2154.

California Department of Fish \& Game, 2009, California Natural Diversity Database Special Animals. Available at: http://www.dfg.ca.gov/biogeodata/cnddb/pdfs/spanimals. pdf.

Churchill, R.K., and Clinkenbeard, J.P., 2002, Assessment of the feasibility of the remediation of mercury mine sources in the Cache Creek Watershed: Assessment of the feasibility of remediation of mercury mine sources in the Cache Creek Watershed. Task 5C1. Final report, California Department of Conservation, California Geological Survey: Prepared for the CALFED Bay-Delta Program. Directed action \#99-B06.

Domagalski, J.L., Alpers, C.N., Slotton, D.G., Suchanek, T.H., and Ayers, S.M., 2004, Mercury and methylmercury concentrations and loads in the Cache Creek Watershed, California: Science of the Total Environment, v. 327, p. 215-237.

Foe, C.G., and Croyle, B., 1998, Mercury concentrations and loads from the Sacramento River and from Cache Creek to the Sacramento - San Joaquin Delta Estuary: Staff report, California Regional Water Quality Control Board, Central Valley Region, Sacramento, California, 101 p.

Foe, C., and Bosworth, D., 2008, Mercury inventory in the Cache Creek Canyon: Staff Report, Central Valley Regional Water Quality Control Board, February 2008, 16 p. Available at: http://www.waterboards.ca.gov/centralvalley/ water_issues/tmdl/central_valley_projects/cache_sulphur_ creek/cache crk rpt.pdf.)

Gassel, M., Klasing, S., Brodberg, R.K., and Roberts, S., 2005, Fish consumption guidelines for Clear Lake, Cache Creek, and Bear Creek (Lake, Yolo, and Colusa counties). Office of Environmental Health Hazard Assessment, Calif. EPA. Available at: http://oehha.ca.gov/fish/so cal/pdf zip/ ClearLake0105.pdf.

Gill, G.A., and Bruland, K.W., 1990, Mercury speciation in surface freshwater systems in California and other areas: Environmental Science and Technology, v. 24, no. 9, p. 1392-1400.

Haines, T.A., May, T.W., Finlayson, R.T., and Mierzykowski, S.E., 2003, Factors affecting food chain transfer of mercury in the vicinity of the Nyanza site, Sudbury River, Massachusetts: Environmental Monitoring and Assessment, v. 86 , p. 211-232.
Hall, B.D., Rosenberg, D.M., and Wiens, A.P., 1998, Methyl mercury in aquatic insects from an experimental reservoir: Canadian Journal of Fisheries and Aquatic Sciences, v. 55, p. 2036-2047.

Hothem, R.L., Trejo, B.S., Bauer,, M.L., and Crayon, J.J., 2008, Cliff swallows Petrochelidon pyrrhonota as bioindicators of environmental mercury, Cache Creek Watershed, California: Archives of Environmental Contamination and Toxicology, v. 55, p. 111-121.

Hothem, R.L., Jennings, M.R., and Crayon, J.J., in press, Mercury contamination in three species of Anuran amphibians from the Cache Creek Watershed, California, USA: Environmental Monitoring and Assessment. (Published online and available at: http://www.springerlink. com/content/n241j80512w06324/fulltext.pdf)

Huckabee, J.W., Elwood, J.W., and Hildebrand, S.G., 1979, Accumulation of mercury in freshwater biota, in Nriagu, J.O., ed., Biogeochemistry of mercury in the environment: New York, Elsevier/North-Holland Biomedical Press, p. 277-302.

Hurley, J.P., Cowell, S.E., Shafer, M.M., and Hughes, P.E., 1998, Tributary loading of mercury to Lake Michigan: Importance of seasonal events and phase partitioning: Science of the Total Environment, v. 213, p. 129-137.

Janik, C.J., Goff, F., and Rytuba, J.J., 1994, Mercury in waters and sediments of the Wilbur Hot Springs area, Sulphur Creek Mining District, California: EOS Transactions American Geophysical Union, v. 75, no. 44, p. 243.

Jardine, T.D., Al, T.A., MacQuarrie, K.T.B., Ritchie, C.D., Arp, P.A., Maprani, A., and Cunjak, R.A., 2005, Water striders (family Gerridae): mercury sentinels in small freshwater ecosystems: Environmental Pollution, v. 134, p. 165-171.

Jardine, T.D., Kidd, K.A., Cunjak, R.A., and Arp, P.A., 2009, Factors affecting water strider (Hemiptera: Gerridae) mercury concentrations in lotic systems: Environmental Toxicology and Chemistry, v. 28, issue 7, p. 1480-1492.

Jennings, M. R., and Hayes, M.P., 1994, Amphibian and reptile species of special concern in California: California Department of Fish and Game, Inland Fisheries Division, Rancho Cordova, CA, 255 p. Available at: http://www.dfg. ca.gov/habcon/info/herp ssc.pdf.

Kim, C.S., Brown Jr., G.E., and Rytuba, J.J., 2000, Characterization and speciation of mercury-bearing mine wastes using X-ray absorption spectroscopy: Science of the Total Environment, v. 261, p. 157-168. 
Mason, R.P., Laporte, J.-M., and Andres, S., 2000, Factors controlling the bioaccumulation of mercury, methylmercury, arsenic, selenium, and cadmium by freshwater invertebrates and fish: Archives of Environmental Contamination and Toxicology, v. 38, p. 283-297.

May, J.T., Hothem, R.L., Alpers, C.N., and Law, M.A., 2000, Mercury bioaccumulation in fish in a region affected by historic gold mining: the South Yuba River, Deer Creek, and Bear River watersheds, California, 1999: U.S. Geological Survey, Open-file Report 00-367, 30 p. Available at: http:// pubs.er.usgs.gov/usgspubs/ofr/ofr00367.

Meador, M.R., Cuffney, T.F., and Gurtz, M.E., 1993, Methods for sampling fish communities as part of the National Water-Quality Assessment Program. U.S. Geological Survey Open-File Report 93-104, 40 p.

Merritt, R.W., and Cummins, K.W., 1995, An introduction to the aquatic insects of North America ( $2^{\text {nd }}$ ed.):Dubuque, Iowa, Kendall/Hunt, 862 p.

Moulton, S.R., II, Kennen, J.G., Goldstein, R.M., and Hambrook, J.A., 2002, Revised protocols for sampling algal, invertebrate, and fish communities as part of the National Water-Quality Assessment Program: U.S. Geological Survey Open-File Report 02-150, 72 p. Available at: http://pubs.er.usgs.gov/usgspubs/ofr/ofr02150.

Nelson, G.C., Rytuba, J.J., McLaughlin, R.J., and Tosdal, R.M., 1993, Gold and mercury deposits in the Sulphur Creek District, California, in Rytuba, J.J., ed., Active geothermal systems and gold-mercury deposits in the Sonoma-Clear Lake volcanic fields, California: Society of Economic Geologists Guidebook Series, v. 16, p. 262-269.

Olson, M.L., and DeWild, J., 1999, Low-level collection techniques and species-specific analytical methods for mercury in water, sediment, and biota: U.S. Geological Survey Water-Resources Investigations Report 99-4018b, $11 \mathrm{p}$.

Peters, E.K., 1991, Gold-bearing hot spring systems of the northern Coast Ranges, California: Economic Geology, v. 86, no. 7, p. 1519-1528.

Riscassi, A.L., and Scanlon, T.M., 2008, Investigation of automated sampling techniques to measure total mercury in stream-water during storm-events, Eos Transactions American Geophysical Union, 89(53), Fall Meeting Supplement, Abstract B13C-0456.
Scherbatskoy, T., Shanley, J.B., and Keeler, G.J., 1998, Factors controlling mercury transport in an upland forested catchment: Water, Air, and Soil Pollution, v. 105, p. 427438.

Schwarzbach, S., Thompson, L., and Adelsbach, T., 2001, An investigation of mercury bioaccumulation in the Upper Cache Creek Watershed, 1997-1998: U.S. fish and Wildlife Service Final Report, Environmental Contaminants Division Off Refuge Investigations Report FFS \#1130 1F22, DEC ID \#199710005, July 2001, 43 p.

Scudder, B.C., Chasar, L.C., DeWeese, L.R., Brigham, M.E., Wentz, D.A., and Brumbaugh, W.G., 2008, Procedures for collecting and processing aquatic invertebrates and fish for analysis of mercury as part of the National Water-Quality Assessment Program: U.S. Geological Survey Open-File Report 2008-1208, 34 p. Available at: http://pubs.usgs.gov/ of/2008/1208/.

Shelton, L.R., and Capel, P.D., 1994, Guidelines for collecting and processing samples of stream bed sediment for analysis of trace elements and organic contaminants for the National Water-Quality Assessment Program: U.S. Geological Survey Open-File Report 94-458, 20 p. Available at: $\underline{\text { http:// }}$ pubs.er.usgs.gov/usgspubs/ofr/ofr94458.

Slotton, D.G., Ayers, S.M., Reuter, J.E., and Goldman, C.R., 1997, Cache Creek watershed preliminary mercury assessment, using benthic macro-invertebrates: Final Report to the Central Valley Regional Water Quality Control Board and The National Science Foundation, 36 p.

Slotton, D.G., Ayers, S.M., Suchanek, T.H., Weyand, R.D., and Liston, A.M., 2004, Mercury bioaccumulation and trophic transfer in the Cache Creek Watershed of California, in relation to diverse aqueous mercury exposure conditions: Component 5B of the multi-institutional directed action research project: Assessment of ecological and human health impacts of mercury in the San Francisco Bay-Delta Watershed. Final Report to CALFED, January 25, 2004, $74 \mathrm{p}$.

Slowey, A.J., and Rytuba, J.J., 2008, Mercury release from the Rathburn Mine, Petray Mine, and Bear Valley saline springs, Colusa County, California, 2004-2006: U.S. Geological Survey Open-File Report 2008-1179, 49 p. Available at: http://pubs.usgs.gov/of/2008/1179/.

Smith, C.N., Kesler, S.E., Blum, J.D., and Rytuba, J.J., 2008, Isotope geochemistry of mercury in source rocks, mineral deposits and spring deposits of the California Coast Ranges, USA: Earth and Planetary Science Letters, v. 269, p. 399407. 
Suchanek, T.H., Slotton, D.G., Nelson, D.C., Ayers, S.M., Asher, C., Weyand, R., Liston, A., and Eagles-Smith, C., 2004, Mercury loading and source bioavailability from the Upper Cache Creek Mining Districts: Component 5A of the multi-institutional directed action research project: assessment of ecological and human health impacts of mercury in the San Francisco Bay-Delta Watershed. Final Report to CALFED. 72 p. Available at: http://mercury.mlml. calstate.edu/wp-content/uploads/2008/12/finalrpt-task-5aths-calfed5a-9-03.pdf.

Suchanek, T.H., Richerson, P.J., Zierenberg, R.A., EaglesSmith, C.A., Slotton, D.G., Harner, E.J., Osleger, D.A., Anderson, D.W., Cech, J.J., Jr., Schladow, S.G., Colwell, A.E., Mount, J.F., King, P.S., Adam, D.P., and McElroy, K.L., 2008a, The legacy of mercury cycling from mining sources in an aquatic ecosystem: from ore to organism: Ecological Applications, v. 18, no. 8, Supplement, p. A12-A28. Available at: http://www.esajournals.org/doi/ pdf/10.1890/08-0363.1.

Suchanek, T.H., Eagles-Smith, C.A., and Harner, E.J., 2008b, Is Clear Lake methylmercury distribution decoupled from bulk mercury loading?: Ecological Applications, v. 18, no. 8, Supplement, p. A107-A127. Available at: http://www. esajournals.org/doi/pdf/10.1890/06-1649.1.

Suchanek, T.H., Cooke, J., Keller, K., Jorgensen, S., Richerson, P.J., Eagles-Smith, C.A., Harner, E.J., and Adam, D.P., 2009, A mass balance mercury budget for a mine-dominated lake: Clear Lake, California: Water, Air, and Soil Pollution, v. 196, p. 51-73.
Tetra Tech EM Inc., 2003, Final engineering evaluation and cost analysis for the Sulphur Creek Mining District, Colusa and Lake Counties, California: Final report for CALFED Cache Creek Study, Task 5C2, 393 p.

U.S. Bureau of Mines, 1965, Mercury potential of the United States: Information Circular 8252, U.S. Department of the Interior, Bureau of Mines, $376 \mathrm{p}$.

Walsh, S.J., and Meador, M.R., 1998, Guidelines for quality assurance and quality control of fish taxonomic data collected as part of the National Water-Quality Assessment Program: U.S. Geological Survey Water-Resources Investigations Report 98-4239, 33 p.

Wiener, J.G., and Spry, D.J., 1996, Toxicological significance of mercury in freshwater fish, in Beyer, W.N., Heinz, G.H., and Redmon-Norwood, A.W., eds., Environmental Contaminants in Wildlife: Interpreting Tissue Concentrations: Boca Raton, Fla., Lewis Publishers, p. 297339.

Wiener, J.G., Bodaly, R.A., Brown, S.S., Lucotte, M., Newman, M.C., Porcella, D.B., Reash, R.J., and Swain, E.B., 2007, Monitoring and evaluating trends in methylmercury accumulation in aquatic biota, Chapter 4 in Harris, R.C., Krabbenhoft, D.P., Mason, R.P., Murray, M.W., Reash, R.J., and Saltman, , T., eds., Ecosystem Responses to Mercury Contamination - Indicators of Change: Boca Raton, FL, CRC Press and Society of Environmental Toxicology and Chemistry, p. 87-122.

Zar, J.H., 1999, Biostatistical Analysis, 4th Edition. PrenticeHall Inc., Upper Saddle River, NJ. 
Appendix A. Fish Processing Form for Bear Creek Mercury Study.

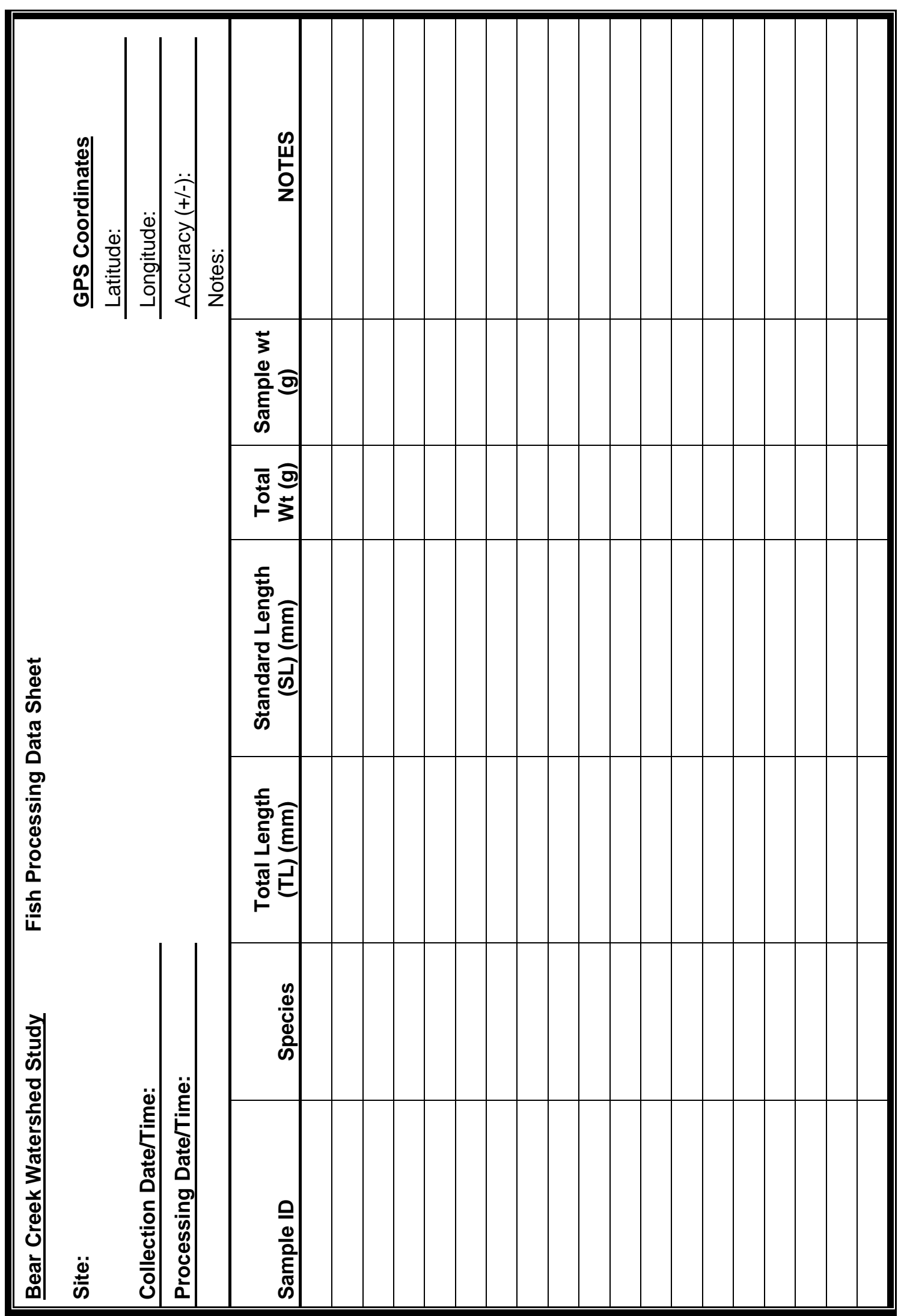




\section{Appendix B. Invertebrate Laboratory Processing Form for Bear Creek Mercury Study.}

\section{Bear Creek Mercury Study}

Invertebrate Processing Data Sheet

Site:

Collection Date/Time:

Processing Date/Time:

GPS Coordinates

Latitude:

Longitude:

Accuracy (+/-):

Notes:

\begin{tabular}{|c|l|l|l|l|l|}
\hline $\begin{array}{c}\text { Jar/ } \\
\text { Sample ID }\end{array}$ & Order & Family & Number & $\begin{array}{c}\text { Wt } \\
\text { (g) }\end{array}$ & \\
\hline & & & & & \\
\hline & & & & & \\
\hline & & & & & \\
\hline & & & & & \\
\hline & & & & & \\
\hline & & & & & \\
\hline & & & & & \\
\hline & & & & & \\
\hline & & & & & \\
\hline & & & & & \\
\hline
\end{tabular}

NOTES: 


\section{Appendix C. Labels for Sample Containers.}

"Unique Sample ID Number"
Family:_/Wt:
"Site Name"

"Unique Sample ID Number" Family: \#/Wt: 1 g.

"Site Name"

"Unique Sample ID Number" Family: \#/Wt:_ I

"Site Name"

"Unique Sample ID Number" Family: \#/Wt:_ I__ g. "Site Name"

"Unique Sample ID Number" Family: \#/Wt: I $\mathrm{l}$ g.

"Site Name"

"Unique Sample ID Number" Family:

\#/Wt:_ I

"Site Name"

"Unique Sample ID Number" Family:

\#/Wt:_l_ g.

"Site Name"

"Unique Sample ID Number" Family: \#/Wt: I $\mathrm{l}$ g.

"Site Name"

"Unique Sample ID Number" Family:

\#/Wt:____ g.

"Site Name"

\author{
"Unique Sample ID Number" \\ Family: \\ \#/Wt:_ /_ g. \\ "Site Name"
}

"Unique Sample ID Number" Family: \#/Wt: I

"Site Name"

"Unique Sample ID Number" Family:

\#/Wt:_ I__ g.

"Site Name"

"Unique Sample ID Number" Family: \#/Wt:_ /_ g. "Site Name"

"Unique Sample ID Number" Family: \#/Wt:_ I "Site Name"

"Unique Sample ID Number" Family:

\#/Wt:____ g.

"Site Name"

"Unique Sample ID Number" Family: \#/Wt:_ I__ g. "Site Name"

"Unique Sample ID Number" Family: \#/Wt: "Site Name"

"Unique Sample ID Number" Family: \#/Wt:_ I__ g.

"Site Name"
"Unique Sample ID Number" Family: \#/Wt:_l_ g. "Site Name"

"Unique Sample ID Number" Family:

\#/Wt:_l_ g.

"Site Name"

"Unique Sample ID Number" Family:

\#/Wt:_ I__ g.

"Site Name"

"Unique Sample ID Number" Family: \#/Wt:_l_ g. "Site Name"

"Unique Sample ID Number" Family: \#/Wt: I g. "Site Name"

"Unique Sample ID Number" Family:

\#/Wt:_ I__ g.

"Site Name"

"Unique Sample ID Number" Family:

\#/Wt: /_ g.

"Site Name"

"Unique Sample ID Number" Family: \#/Wt: I g. "Site Name"

"Unique Sample ID Number" Family:

\#/Wt:_l_ g.

"Site Name" 


\section{Appendix D. Example Chain of Custody Form.}

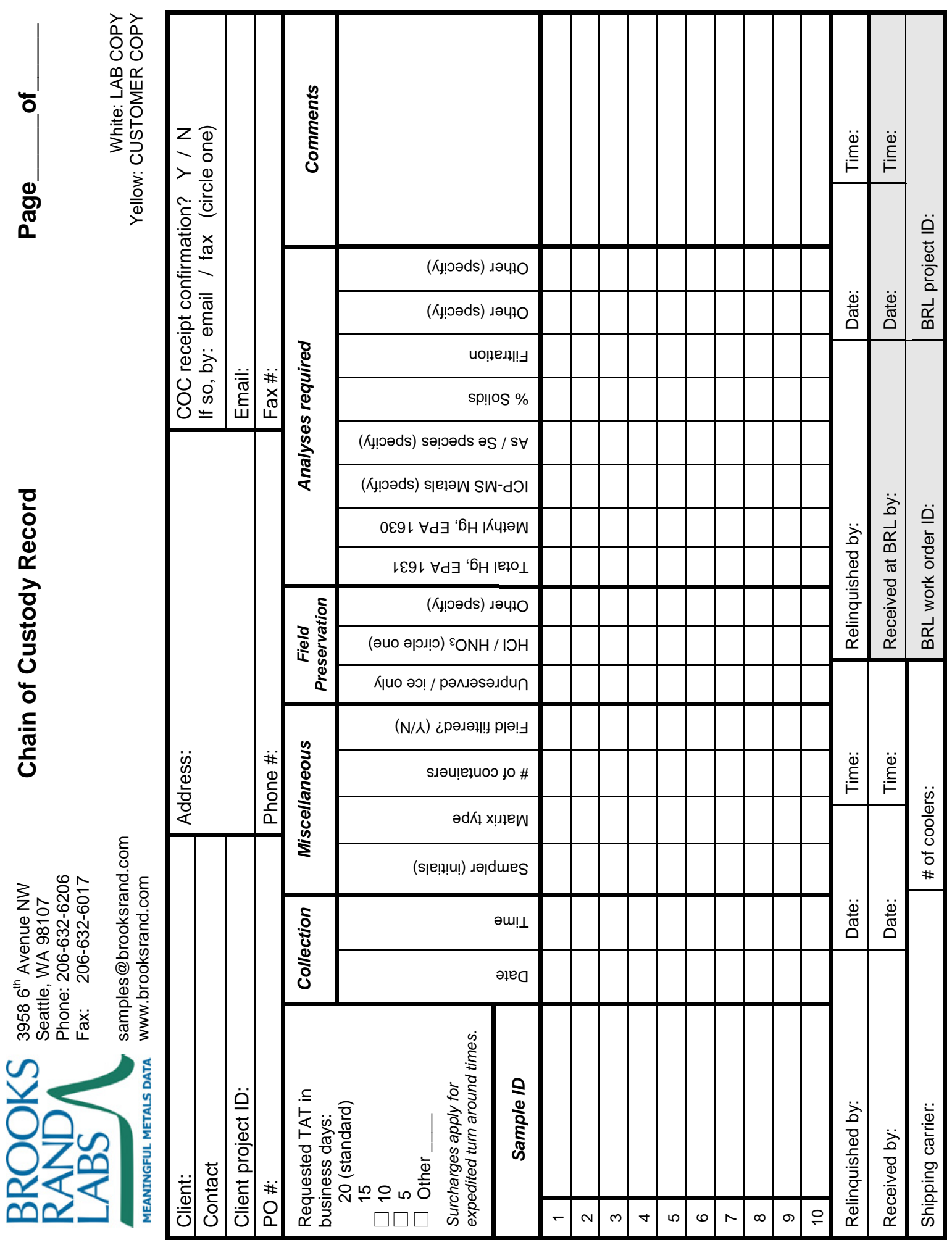


Publishing support provided by the U.S. Geological Survey

Publishing Network, Sacramento and Tacoma Publishing Service

Centers

For more information concerning the research in this report, contact the

Director, Western Ecological Research Center

3020 State University Drive East

Modoc Hall, Room 3006

Sacramento, CA 95819

http://www.werc.usgs.gov/ 


\section{总}

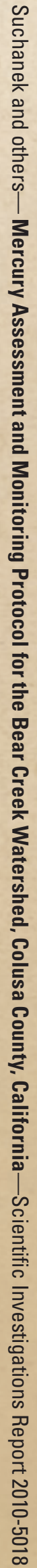

